\title{
Genetic disruption of s/c4a10 alters the capacity for cellular metabolism and vectorial ion transport in the choroid plexus epithelium
}

Inga Baasch Christensen, Qi Wu, Anders Solitander Bohlbro, Marianne Gerberg Skals, Helle Hasager Damkier, Christian Andreas Hübner, Robert Andrew Fenton and Jeppe Praetorius* (D)

\begin{abstract}
Background: Genetic disruption of s/c4a10, which encodes the sodium-dependent chloride/bicarbonate exchanger $\mathrm{Ncbe}$, leads to a major decrease in $\mathrm{Na}^{+}$-dependent $\mathrm{HCO}_{3}{ }^{-}$import into choroid plexus epithelial cells in mice and to a marked reduction in brain intraventricular fluid volume. This suggests that Ncbe functionally is a key element in vectorial $\mathrm{Na}^{+}$transport and thereby for cerebrospinal fluid secretion in the choroid plexus. However, s/c4a10 disruption results in severe changes in expression of $\mathrm{Na}^{+}, \mathrm{K}^{+}$-ATPase complexes and other major transport proteins, indicating that profound cellular changes accompany the genetic manipulation.

Methods: A tandem mass tag labeling strategy was chosen for quantitative mass spectrometry. Alterations in the broader patterns of protein expression in the choroid plexus in response to genetic disruption of Ncbe was validated by semi-quantitative immunoblotting, immunohistochemistry and morphometry.

Results: The abundance of 601 proteins were found significantly altered in the choroid plexus from Ncbe ko mice relative to Ncbe wt. In addition to a variety of transport proteins, particularly large changes in the abundance of proteins involved in cellular energy metabolism were detected in the Ncbe ko mice. In general, the abundance of rate limiting glycolytic enzymes and several mitochondrial enzymes were reduced following s/c4a10 disruption. Surprisingly, this was accompanied by increased ATP levels in choroid plexus cells, indicating that the reduction in capacity for energy metabolism was adaptive to high ATP rather than causal for a decreased capacity for ion and water transport. Ncbedeficient cells also had a reduced cell area and decreased $\mathrm{K}^{+}$content.

Conclusion: Our findings suggest that the lack of effective $\mathrm{Na}^{+}$-entry into the epithelial cells of the choroid plexus leads to a profound change in the cellular phenotype, shifting from a high-rate secretory function towards a more dormant state; similar to what is observed during ageing or Alzheimer's disease.
\end{abstract}

Keywords: Choroid plexus, Cerebrospinal fluid, Ncbe, Mass spectrometry

*Correspondence: jp@biomed.au.dk

Department of Biomedicine, Health, Aarhus University, Wilhelm Meyers Allé 3, r. 219, 8000 Aarhus C, Denmark

\section{Background}

A large fraction of the cerebrospinal fluid (CSF) is produced by the choroid plexus $(\mathrm{CP})$ in the brain ventricles [1]. At this site, the choroid plexus epithelial cells (CPECs) secrete solutes and water at very high rates that is not surpassed by other mammalian epithelia [2]. The

(c) The Author(s) 2020. This article is licensed under a Creative Commons Attribution 4.0 International License, which permits use, sharing, adaptation, distribution and reproduction in any medium or format, as long as you give appropriate credit to the original author(s) and the source, provide a link to the Creative Commons licence, and indicate if changes were made. The images or other third party material in this article are included in the article's Creative Commons licence, unless indicated otherwise in a credit line to the material. If material is not included in the article's Creative Commons licence and your intended use is not permitted by statutory regulation or exceeds the permitted use, you will need to obtain permission directly from the copyright holder. To view a copy of this licence, visit http://creativeco mmons.org/licenses/by/4.0/. The Creative Commons Public Domain Dedication waiver (http://creativecommons.org/publicdomain/ zero/1.0/) applies to the data made available in this article, unless otherwise stated in a credit line to the data. 
mechanisms for water and salt secretion are still debated i.e. the nature of the $\mathrm{Na}^{+}$entry and exit mechanisms, as well as the transepithelial water transport pathways. The luminal $\mathrm{Na}^{+}, \mathrm{K}^{+}$-ATPase is the driving mechanism for solute secretion both through its direct extrusion of $\mathrm{Na}^{+}$into the CSF and by creation of the driving force for secondary active transport processes [3-5]. The canonical water channel, aquaporin 1 (AQP1) is abundant in the luminal membrane of CPECs and is the major water transport pathway in the $\mathrm{CP}$ [6]. As the major $\mathrm{HCO}_{3}{ }^{-}$exit pathway, electrogenic $\mathrm{Na}^{+}: \mathrm{HCO}_{3}{ }^{-}$transport by $\mathrm{NBCe} 2$ most likely contributes to the $\mathrm{Na}^{+}$extrusion by CPECs, while the direction of transport for the $\mathrm{Na}^{+}, \mathrm{K}^{+}, 2 \mathrm{Cl}^{-}$cotransporter 1 (NKCC1) and the possible cotransport of water are matters of current discussion $[7,8]$. The $s l c 4 a 10$ gene product, Ncbe, is a $\mathrm{Na}^{+}: \mathrm{HCO}_{3}{ }^{-}$ import protein abundantly expressed in the basolateral membrane of CPECs, which in rodents couples ion import to $\mathrm{Cl}^{-}$extrusion [9-11]. Genetic disruption of slc4a10 leads to an approximately $80 \%$ decrease in brain ventricle volume mirrored by a cellular $\mathrm{Na}^{+}$dependent $\mathrm{HCO}_{3}{ }^{-}$import. Thus, we have proposed Ncbe as a main candidate for the $\mathrm{Na}^{+}$entry mechanism [12].

Targeted, antibody-based studies of slc4a10 knockout mice (Ncbe ko) relative to wildtype (Ncbe wt) controls, uncovered several changes in the expression of key transporters in CPECs. Notably, two of the most prominent luminal membrane proteins in CSF secretion were affected by the genetic slc4a10 disruption; we found reduced expression levels of the $\mathrm{Na}^{+}, \mathrm{K}^{+}$-ATPase and the AQP1 to approximately $20 \%$ in the Ncbe ko mice, as compared to Ncbe wt mice [13]. The CPECs also displayed inversed localization of the $\mathrm{Na}^{+} / \mathrm{H}^{+}$exchanger NHE1 from the luminal side to the basolateral side in Ncbe ko [14] and further changes in cell polarity, cell contact and anchoring proteins [15]. Many of these changes would be consistent with a reduction of cellular secretory capacity.

Based on these studies, we hypothesized that this very efficient transporting epithelium adapts to the lack of a major ion transporter by shutting down a secretory program and develops into a more dormant epithelial phenotype. To examine this in detail, we initially used a semi-quantitative proteomic approach to comprehensively compare CPECs from Ncbe ko and wt mice. This would delineate the cellular consequences of slc4a10 disruption and generate new hypothesis on cellular adaptations to the loss of a major $\mathrm{Na}^{+}$uptake mechanism. Immunoblotting, semi-quantitative immunofluorescence histochemistry, measurements of cellular ATP and $\mathrm{K}^{+}$ contents, and cell size estimations were also applied to determine additional changes in functional capacities of CPECs evoked by genetic slc4a10 disruption. The major findings are that disruption of slc4a10 alters the capacity for cellular metabolism and vectorial ion transport in the CP epithelium.

\section{Materials and methods \\ Animals}

Heterozygous breeding and genotyping of the slc4a10targeted knockout mouse model have previously been described [12]. The mice were bred on c57bl/6 (Taconic) background, and both female and male mice aging 4-5 weeks were used. All procedures conformed to Danish animal welfare regulations. The authors are licensed to breed the mouse strain by The Animal Experiments Inspectorate, Ministry of Food, Agriculture, and Fisheries of Denmark (j.n. 2012-15-2935-00004).

\section{Tandem mass tag 10-plex isobaric mass tag labelling}

Mice were euthanized under isoflurane anaesthesia, and $\mathrm{CP}$ tissues from all four ventricles of each mouse were isolated in $4{ }^{\circ} \mathrm{C}$ phosphate buffered salt solution (isotonic PBS, in mM: $167 \mathrm{Na}^{+}, 150.0 \mathrm{Cl}^{-}, 2.8 \mathrm{H}_{2} \mathrm{PO}_{4}^{-}, 7.2$ $\mathrm{HPO}_{4}{ }^{2-}, \mathrm{pH}$ 7.4), before the tissues were snap-frozen in liquid nitrogen. The tissues were thawed on ice and 5\% $\mathrm{Na}$-deoxycholate in $50 \mathrm{mM} \mathrm{NH} \mathrm{HCO}_{3}$ with protease inhibitors (Halt ${ }^{\mathrm{TM}}$ Protease Inhibitor Cocktail, Thermo Scientific) was added before sonication and centrifugation at $16,000 \times g$ for $10 \mathrm{~min}$ at $4{ }^{\circ} \mathrm{C}$. The resulting supernatants were concentrated on spin columns (Amicon ${ }^{\circledR}$ Ultra $0.5 \mathrm{~mL}, 3 \mathrm{kDa}$ cut-off, $14,000 \times g$ ). The samples were reduced, alkylated and digested on the column using Lysyl Endopeptidase (Lys C, Wako), and trypsin (Promega) before elution from the columns and measurement of peptide concentration (Pierce Quantitative fluorometric Peptide Assay).

A total of 9 samples each containing $35 \mu \mathrm{g}$ peptides from one male and one female mouse of the same genotype (a total of $70 \mu \mathrm{g}$ peptide) were labelled for TMT according to the manufacturer's instructions $(\mathrm{n}=4$ for Ncbe ko, and $n=5$ for Ncbe wt, TMT10plex ${ }^{\text {TM }}$ Label Reagent Set, Thermo Fisher Scientific). The total amount of protein in Ncbe ko samples was $68.7 \pm 2.9 \%$ of Ncbe wt $\left(100 \pm 3.9 \%, p=8.3 \times 10^{-6}\right)$. Equal amounts of peptides from each labelling reaction were pooled, and the sample was desalted on a C18 column (Oasis HLB 1 cc Extraction Cartridges, Waters). The $128 \mathrm{C}$ channel was used as control label to normalize across different mass spectrometry runs (denominator). All other channels were compared to the $128 \mathrm{C}$ channel to calculate a normalized ratio.

\section{Mass spectrometry (MS) analysis}

The TMT labelled samples were analysed by nano Liquid chromatography (nLC) (easy LC 1000, Thermo Fisher) coupled to a mass spectrometer (Q Exactive, 
Thermo Scientific) through an EASY-Spray nano-electrospray ion source (Thermo Scientific). A pre-column (Acclaim ${ }^{\circledR}$ PepMap 100, $75 \mu \mathrm{m} \times 2 \mathrm{~cm}, \mathrm{C} 18,3 \mu \mathrm{m}, 100$ $\AA$, Thermo Scientific) and analytical column (EASYSpray Column, PepMap, $75 \mu \mathrm{m} \times 25 \mathrm{~cm}, \mathrm{C} 18,3 \mu \mathrm{m}$, $100 \AA$, Thermo Scientific) were used to trap and separate peptides, respectively. For nLC separation, buffer A was $100 \% \mathrm{H}_{2} \mathrm{O} / 0.1 \%$ formic acid and buffer B was $100 \%$ ACN $/ 0.1 \%$ formic acid. A linear gradient from $5 \%$ to $20 \%$ buffer B for $24 \mathrm{~min}$, and then from $20 \%$ to $35 \%$ for 12 min were used for separation of peptides. Precursor scan was performed at a resolution of 70,000, maximum injection time of $100 \mathrm{~ms}$ and automatic gain control of $3 \times 10^{6}$. Up to 10 data-dependent tandem mass spectrometry (MS/MS) scans were performed at a resolution of 35,000, maximum injection time of $100 \mathrm{~ms}$ and AGC of $1 \times 10^{5}$. HCD normalized collision energy (NCE) was set at $30 \%$ with stepped NCE of $20 \%$. Fixed first mass was set at 115 . Dynamic exclusion of $30 \mathrm{~s}$ as well as rejection of precursor ions with charge state +1 and above +8 was employed.

\section{MS data analysis}

Raw files were searched against a mouse protein database (RefSeq database downloaded Nov. 2015 containing 57925 sequences) using both the Sequest and Mascot algorithms (version 2.5.1, Matrix Science) through Proteome Discoverer software (version 2.1, Thermo Scientific). Precursor mass tolerance was set as $10 \mathrm{ppm}$ and fragment mass tolerance was set as $0.02 \mathrm{Da}$, and a maximum of 2 miss cleavage sites. Carbamidomethylation of cysteine was set as a static modification. N-terminal acetylation, methionine oxidation, TMT labelling of $\mathrm{N}$-terminus and lysine, as well as phosphorylation of serine, threonine and tyrosine were set as variable modifications. False discovery rate (FDR) of $1 \%$, calculated by Percolator, was employed as the cut-off. Peptides identified and quantified in all channels were subjected to Benjamini-Hochberg (BH) FDR estimations, and those that passed the $1 \%$ BH-FDR threshold were retained for further analysis. Gene Ontology annotation and analysis was performed with PANTHER (Protein ANalysis THrough Evolutionary Relationships) Classification System version $11[16,17]$.

\section{Immunoblotting}

Dissected mouse choroid plexi were dissolved in ice-cold dissection buffer containing $0.3 \mathrm{M}$ sucrose, $25 \mathrm{mM}$ imidazole, $1 \mathrm{mM}$ EDTA, $8.4 \mu \mathrm{M}$ leupeptin (Calbiochem), and $0.4 \mathrm{mM}$ Pefabloc (Roche), with $\mathrm{pH}$ 7.2, and sonicated using a probe sonicator (BioLogics Inc. $150 \mathrm{~V} / \mathrm{T}$, $3 \times 5$ bursts at $60 \%$ power). Protein contents were quantified (Pierce BCA Protein Assay Kit) and samples were adjusted to $1.5 \%$ (wt/vol) sodium dodecyl sulfate, $40.0 \mathrm{mM}$ 1,4-dithiothreitol, 6\% (vol/vol) glycerol, and $10 \mathrm{mM}$ Tris, pH 6.8 with bromophenol blue. The samples were heated at $65{ }^{\circ} \mathrm{C}$ for $15 \mathrm{~min}$ and approximately $10 \mu \mathrm{g}$ of protein per sample was separated by $12.5 \%$ polyacrylamide gel electrophoresis and electrotransferred onto PVDF membranes (Ambion). The membranes were blocked with $5 \%$ milk in PBS-T (PBS with $0.1 \% \mathrm{vol} / \mathrm{vol}$ Tween), and incubated overnight at $4{ }^{\circ} \mathrm{C}$ with primary antibody (Table 1) in PBS containing $1 \%$ bovine serum albumin (BSA) and $2 \mathrm{mM} \mathrm{NaN}_{3}$. After extensive washing in PBS-T, the blots were incubated with horseradish peroxidase-conjugated anti-rabbit secondary antibody (Dako), washed again in PBS-T and developed with ECL before imaging (ImageQuant LAS4000, GE Healthcare). The $\mathrm{CP}$ from one mouse only yields in the range $60-100 \mu \mathrm{g}$ of protein sample. To increase the number of blots per experimental animal, the membranes were divided for high-, medium-, and low-molecular proteins prior to antibody incubation. For semi-quantitation, band intensities were normalized to the immunoblot signal for proteasome $20 \mathrm{~s}$ for the same membrane and lane.

\section{Table 1 Primary antibodies used in this study}

\begin{tabular}{|c|c|c|c|}
\hline Target & Antibody number & Host & Source \\
\hline Ncbe & 1139AP & Rabbit & Own laboratory \\
\hline AQP1 & 2353AP & Rabbit & Own laboratory \\
\hline Na,K-ATPase $\beta 1$ & SpET $\beta 1$ & Rabbit & Martín-Vasallo [39] \\
\hline Na,K-ATPase a 1 & $3 B-0 / 56-0$ & Mouse & Forbush, 3rd [40] \\
\hline $\begin{array}{l}\mathrm{Na}, \mathrm{K}, \mathrm{Cl} \text { cotrans- } \\
\text { porter } 1\end{array}$ & N-term. NKCC1 & Rabbit & Turner [41] \\
\hline Anion exchanger 2 & 9899 C-terminal & Rabbit & Alper [42] \\
\hline a2-spectrin & LS-C137722 & Rabbit & LifeSpan Biosciences \\
\hline Ankyrin-3 & sc-28561(H-215) & Rabbit & Santa Cruz Biotech \\
\hline P-cadherin & PAB013Mu01 & Mouse & Cloud Clone Corp. \\
\hline a-catenin & LS-B4457 & Goat & LifeSpan Biosciences \\
\hline$\beta$-catenin & sc-7199(H-102) & Rabbit & Santa Cruz Biotech \\
\hline Ezrin & sc-6409 (C-15) & Goat & Santa Cruz Biotech \\
\hline Moesin & ab50007 & Mouse & Abcam \\
\hline a-adducin & sc-25731 (H-100) & Rabbit & Santa Cruz Biotech \\
\hline PGC-1a & MBS840561 & Rabbit & MyBiosource \\
\hline TUFM & HPA018991 & Mouse & Atlas Antibodies \\
\hline CTCF & sc-271474 & Mouse & Santa Cruz Biotech \\
\hline Cytochrome C & sc-13156 & Mouse & Santa Cruz Biotech \\
\hline $\begin{array}{l}\text { Glycogen phos- } \\
\text { phorylase }\end{array}$ & LS-B13107-50 & Rabbit & LifeSpan Biosciences \\
\hline $\begin{array}{l}\text { pS373SPAK } \\
\text { pS325OSR1 }\end{array}$ & $07-2273$ & Rabbit & Millipore \\
\hline $\begin{array}{r}\text { pS380SPAK } \\
\text { p332OSR1 }\end{array}$ & pS380-SPAK & Rabbit & Shibuya [43] \\
\hline IRBIT (AHCYL1) & sc-271581 & Mouse & Santa Cruz Biotech \\
\hline Proteasome 20s & Ab3325 & Rabbit & Abcam \\
\hline
\end{tabular}




\section{Tissue fixation and immunohistochemistry}

Mice were perfusion fixed via the heart with $4 \%$ paraformaldehyde in PBS. After fixation, the brain was removed, post-fixed for $2 \mathrm{~h}$, dehydrated in $\mathrm{EtOH}$ and xylene, and embedded in paraffin wax, enabling $2 \mu \mathrm{m}$ sectioning using a rotary microtome (Leica). The sections were de-waxed and stepwise rehydrated, before epitopes were retrieved by boiling the sections in TEG buffer: $10 \mathrm{mM}$ Tris buffer with $0.5 \mathrm{mM}$ EGTA (pH 9), or in $10 \mathrm{mM}$ citrate-buffer $(\mathrm{pH} 6)$. The epitopes were quenched with $50 \mathrm{mM} \mathrm{NH}_{4} \mathrm{Cl}$ in PBS, and unspecific binding was blocked by washing with $1 \%$ BSA in PBS with $0.2 \%$ gelatin and $0.05 \%$ saponin. Sections were incubated overnight at $4{ }^{\circ} \mathrm{C}$ with primary antibody diluted in $0.1 \%$ BSA in PBS with $0.3 \%$ Triton X-100. Primary antibodies are listed in Table 1. For fluorescence visualization of the primary antibodies, AlexaFluor 488- or 555-coupled donkey anti-goat, -rabbit, or -mouse secondary antibodies (Invitrogen) were used, and cell nuclei were visualized using Topro-3 counterstaining (Invitrogen). Sections were mounted with a coverslip in Glycergel anti-fade medium (DAKO) and analyzed using a Leica DMIRE2 inverted microscope with a TC5 SPZ confocal unit using a $\times 63 / 1.32$ NA HCX PI Apo oil objective.

\section{Image analysis}

Protein abundance was investigated by quantifying the immunofluorescence intensities from confocal micrographs. All tissues were carefully handled in parallel from the time of fixation throughout embedding, sectioning, staining, and imaging. To avoid saturation of the photomultiplier, the intensity dynamic range (gain and offset) was adjusted to span the intensities of the most intense sample for each antibody. Images were acquired in the focal plane with the highest signal intensity using fixed settings for magnification, laser power, gain, image depth, offset, and averaging for all images with a given antibody.

The immunofluorescence intensities of the stained tissue was quantified from gray-scale images using Image Pro (Media Cybernetics). For each image, the area of interest was manually defined to avoid counts from nonchoroidal tissue or artifacts (Additional file 1: Figure S1). A binary mask of the total area of interest was produced from the fluorescence image. Finally the minimal value for each image pixel was obtained allowing calculation of the total fluorescence count above background within the area of interest (the specific epithelial immunolabeling). For all quantifications, the fluorescence signal was normalized to cell numbers by counting nuclei within the area of interest. All analyzed images were from 4th ventricle CP. In Scatter plots, data are normalized to the mean wild type fluorescence signal. A similar strategy was applied to estimate the average epithelial cell areas as a proxy for cell volume.

\section{Adenosine triphosphate (ATP) assay, and $\mathrm{K}^{+}$content measurements}

Mice were euthanized under isoflurane anaesthesia and $\mathrm{CP}$ from all four ventricles of each mouse were isolated in $4{ }^{\circ} \mathrm{C}$ Hepes-buffered salt solution (HBS, pH 7.4). Each $\mathrm{CP}$ tissue sample was weighed, snap-frozen in liquid nitrogen for cell lysis, added $100 \mu \mathrm{L}$ Milli-Q water and boiled for $1 \mathrm{~min}$ to inhibit ecto-ATPase activity. A fraction of the samples were used for an ATP-determination assay using firefly luciferase. The luminescent signal was recorded on a plate reader (Mithras LB 940, Berthold Technologies). The remainings of the solubilized CP samples were diluted and used for measuring $\mathrm{Na}^{+}$and $\mathrm{K}^{+}$ levels by flame photometry (FLM3, Radiometer).

\section{Co-immunoprecipitation}

CPs were lysed in $50 \mathrm{mM}$ Tris- $\mathrm{HCl} \mathrm{pH} \mathrm{7.4,} 150 \mathrm{mM}$ $\mathrm{NaCl}, 0.25 \%$ Na-Deoxycholate, $1 \%$ Triton X-100, $1 \mathrm{mM}$ EDTA, $20 \mathrm{mM} N$-ethylmaleimide, containing protease inhibitors Leupeptin and Phefa-block (Boehringer Mannheim) and phosphatase inhibitor cocktail tablets (PhosSTOP, Roche Diagnostics). Following sonication, samples were centrifuged at $10,000 \times g$ for $10 \mathrm{~min}$ at $4{ }^{\circ} \mathrm{C}$. Samples were assayed for protein concentration and immunoprecipitation was performed at $4^{\circ} \mathrm{C}$ for $1 \mathrm{~h}$ using $\sim 150 \mu \mathrm{g}$ of lysate and $1 \mu \mathrm{g}$ of anti-Ncbe or anti-proteasome $20 \mathrm{~s}$ antibodies in a total volume of $500 \mu \mathrm{L}$. Lysates were subsequently incubated with $20 \mu \mathrm{L}$ of protein-Aagarose (Santa Cruz Biotechnology) followed by washing three times with lysis buffer and elution in sample buffer and processed for mass spectrometry.

\section{Proximity ligation assay (PLA)}

Immunolabeling was performed as above, but instead of secondary antibody, PLA MINUS and PLUS probes were added, and the labelling with orange detection reagent was performed according to manufacturer's protocol (Duolink, Sigma). Images were acquired as above with $543 \mathrm{~nm}$ laser excitation and emission range $570-650 \mathrm{~nm}$.

\section{Statistical analysis}

A two-tailed $t$-test was used to compare changes between groups (For MS data analysis: Excel, Microsoft, and for all other data: InStat, GraphPad Software). A level of $\mathrm{p}<0.05$ was considered adequate to indicate statistical significance. The exact p-values for mass spectrometry analysis are shown in tables or in the linked database. 


\section{Results}

Ncbe ko greatly alters the general protein expression profile in the $C P$

Mass spectrometry combined with a TMT labeling strategy identified 1865 proteins in all 9 samples. Of these, 601 were significantly changed in abundance in Ncbe ko CP (390 proteins increased, 211 proteins decreased). 340 proteins were increased in abundance by more than $10 \%$, of which 86 were increased more than $25 \%$. Conversely, 183 proteins decreased in abundance by more than $10 \%$, of which 34 decreased by more than $25 \%$. Thus, in general, more proteins were increased in abundance than decreased in Ncbe ko CP, despite an appropriate centering of the data around zero-fold change in the volcano plot (Fig. 1a).

Table 2 lists the 20 proteins with lowest relative abundance in Ncbe ko cells compared to Ncbe wt cells isolated from the CP. The protein most affected by deletion of slc4a10 is, as expected, Ncbe itself. Several N-terminal peptides of Ncbe can still be detected in the Ncbe ko, as the stop codon in the gene modified mouse was introduced after the $\mathrm{N}$-terminus coding region. A total of 8 plasma membrane transport proteins including 4 $\mathrm{Na}^{+}, \mathrm{K}^{+}$-ATPase subunits $(\alpha 1, \alpha 4, \beta 1$, and phospholemman), and 5 enzymes -4 of which are involved in ATP synthesis or transport-are also decreased in abundance. In general, these results support the idea of a decreased capacity for secretion and ATP production, respectively, in Ncbe ko cells. Five proteins normally originating from the blood (the hemoglobins and anti-trypsins), were also detected previously in a proteomic study of FACS isolated single CPECs [18], along with the neuronal membrane glycoprotein M6-a.

Table 3 lists the 20 proteins with the highest relative abundance in Ncbe ko CP compared to Ncbe wt CP. Four of these proteins are involved in regulation or protein breakdown (OSR1, IRBIT, Ceacam-2 and the E2 ligase), and one is a chromosomal protein (HMG-17). Additionally, one protein is involved in glycogen metabolism and one in glucuronidation of water insoluble substances. The two proteins in the list normally arising from neurons or glia (Purkinje cell protein 4 and glial fibrillary acidic protein 2, respectively) were both detected previously in FACS isolated single CPECs [18]. These proteins are therefore considered expressed by CPECs or taken up by the epithelial cells or Kolmer cells (choroid plexus macrophages), which would be the only probable contaminating cell in the referred study.

All detected CP proteins were classified using Gene Ontology (GO) annotation. Figure $1 \mathrm{~b}-\mathrm{g}$ show the distribution of the identified proteins among the GO-terms within the groups: molecular function, cellular component, and biological process, respectively. For molecular function, the proteins were predominantly enzymes, molecule binding proteins, structure molecules, and transporters (Fig. 1b). Figure 1c highlights that more proteins involved in binding and structure molecules are increased in Ncbe ko compared to Ncbe wt. For catalytic activity and transporter activity, the opposite is observed; more proteins are decreased than increased in abundance in Ncbe ko compared to Ncbe wt. Cell structures, organelles, macromolecular complexes and membrane proteins dominated the group "cellular processes" (Fig. 1d). Figure 1e illustrates that there are similar numbers of increasing and decreasing proteins in each group except for the "membrane" and "extracellular region" groups. Here, more proteins decrease in abundance rather than increase in Ncbe ko CP compared to Ncbe wt CP. For biological processes, most proteins belonged to metabolic processes, cell processes, and cell architecture (Fig. 1f). As shown in Fig. 1g, more proteins annotated to metabolic processes and biological regulation decrease than increase in abundance in Ncbe ko. The opposite is observed for cellular processes and cellular organization. Taken together, the data indicate that Ncbe ko cells have less catalytical or metabolical capacity, are less secretory active than Ncbe wt cells, and that structural and morphological changes occur in Ncbe ko CPECs.

\section{Changes in transporter abundance indicate a lower secretory capacity in the Ncbe ko CP}

Plasma membrane transporters were a major class of altered proteins in CPECs from Ncbe ko mice). Many of the proteins with decreased abundance in Ncbe ko mice are closely associated to the secretion of cerebrospinal fluid by the CP. While the abundance of the classical epithelial $\mathrm{Na}^{+}, \mathrm{K}^{+}$-ATPase subunits $\alpha 1$ and $\beta 1$ were reduced to approximately $60 \%$ in the Ncbe ko, the alternative $\alpha 2$, $\alpha 3$ and $\beta 2$ subunits were increased by $10-20 \%$ in Ncbe ko than Ncbe wt CP. Figure $2 \mathrm{a}-\mathrm{h}$ shows immunoblot validation of the TMT 10-plex data for 5 transporters with decreasing abundance and 1 transporter with increased abundance along with proteasome $20 \mathrm{~s}$ loading controls (Ncbe $\mathrm{p}<0.0001 ; \mathrm{AQP} 1, \mathrm{p}=0.0003 ; \mathrm{Na}^{+}, \mathrm{K}^{+}$-ATPase $\beta 1 \mathrm{p}=0.0055 ; \mathrm{Na}^{+}, \mathrm{K}^{+}$-ATPase $\alpha 1 \mathrm{p}=0.0014 ; \mathrm{NKCC} 1$ $\mathrm{p}=0.059$; Anion exchanger 2 , Ae2, $\mathrm{p}=0.0171 ; \mathrm{n}=5$ ). Apart from NKCC1, immunofluorescence histochemistry was previously used to determine changes in the abundance of these transporters in the same mouse model [13-15]. Figure 2i, j show representative images used for semi-quantification illustrating reduced NKCC1 abundance in Ncbe ko vs. Ncbe wt CP. Data obtained by immunofluorescence microscopy, mass spectrometry, and immunoblotting are compared in Fig. 2k (for NKCC1 immunofluorescence: $\mathrm{p}=0.0030, \mathrm{n}=5$ ). There is a general agreement among the techniques except for NKCC1, 


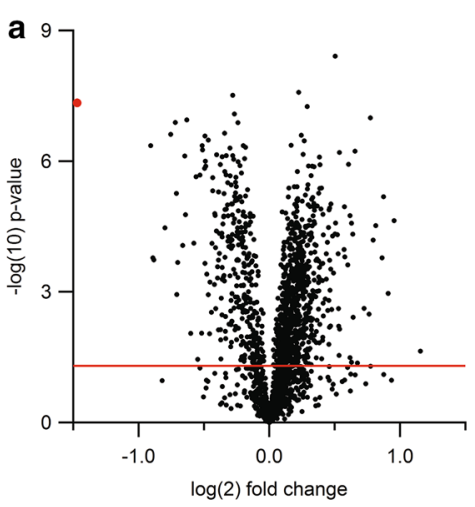

b

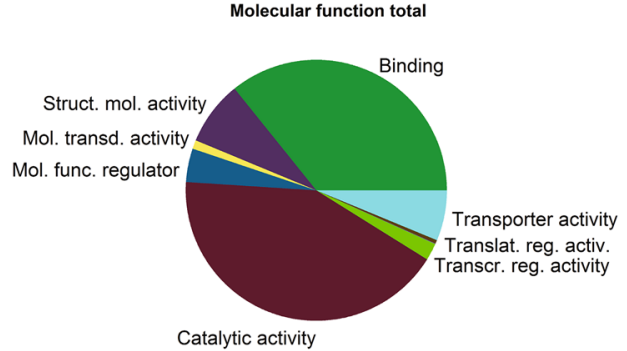

d

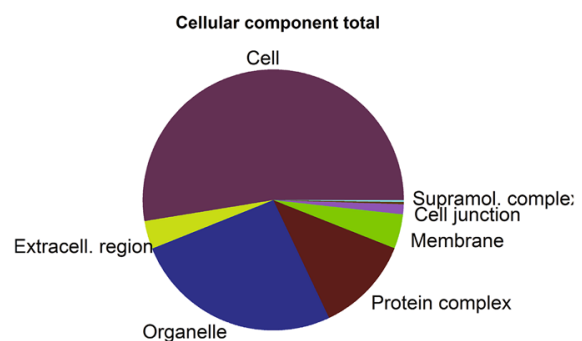

f

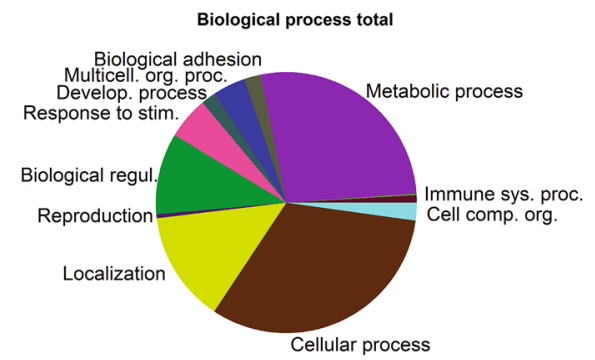

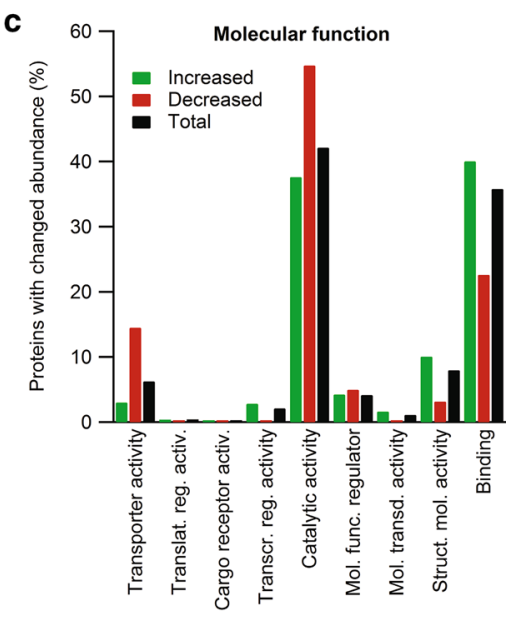
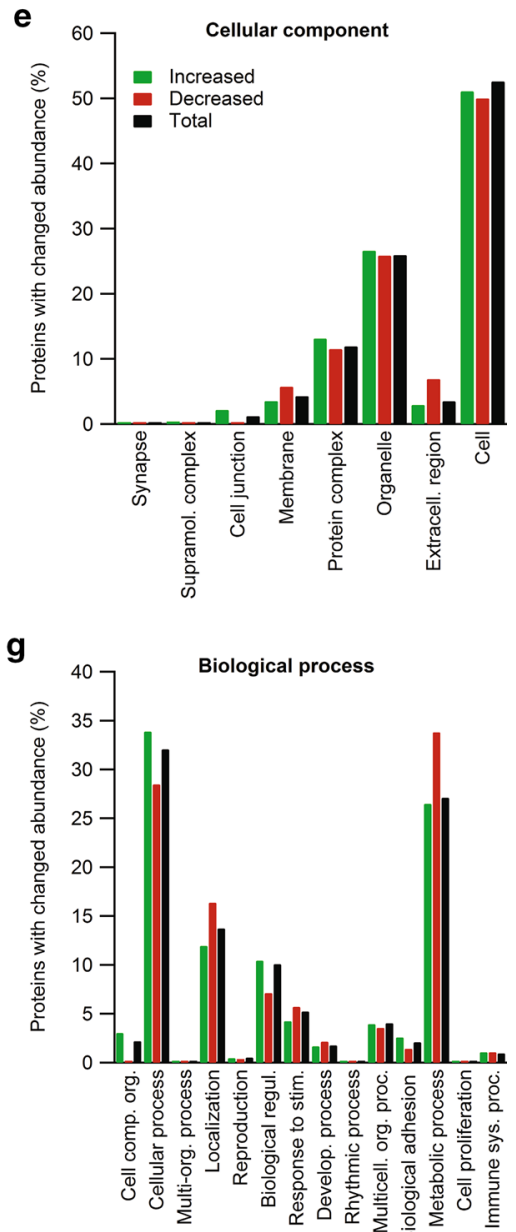

Fig. 1 Proteomic and bioinformatic profile of the CP from Ncbe wt and Ncbe ko mice. a Volcano plot of the peptide quantification in Ncbe wt and Ncbe ko CP, where the primary axis shows the $\log _{2}$ (mean peptide abundance ratio), while the secondary axis designates the $-\log _{10}(p$ value). The horizontal red line represents the Benjamini-Hochberg false discovery rate threshold $(p=0.05)$. The red dot marks the data point for Ncbe peptides encoded by pre-STOP codons. Pie and bar graphs visualizing the distribution of proteins detected in both groups classified by gene ontology (GO) terms for molecular functions $(\mathbf{b}, \mathbf{c})$, cellular components $(\mathbf{d}, \mathbf{e})$, and biological processes $(\mathbf{f}, \mathbf{g})$. The bar graphs illustrate the percent wise distribution of proteins among GO-terms topics for all detected proteins (black bars), and proteins that are either increased (green bars) or decreased (red bars) in Ncbe ko CP compared to Ncbe wt 
Table 2 Proteins with lowest relative abundance in CP from Ncbe ko compared to Ncbe wt mice

\begin{tabular}{|c|c|c|c|}
\hline Accession & Description & p-value & Ratio \\
\hline 334688852 & Sodium-driven chloride bicarbonate exchanger 1 & $4.57 \mathrm{E}-08$ & 0.36 \\
\hline 6753138 & Sodium/potassium-transporting ATPase subunit $\beta-1$ & $4.40 \mathrm{E}-07$ & 0.53 \\
\hline 145301549 & Hemoglobin a, adult chain 2 & $1.66 \mathrm{E}-04$ & 0.54 \\
\hline 31982300 & Hemoglobin, $\beta$ adult t chain & $1.84 \mathrm{E}-04$ & 0.54 \\
\hline 254588010 & Aminopeptidase Q & $3.41 \mathrm{E}-05$ & 0.57 \\
\hline 21450277 & Sodium/potassium-transporting ATPase subunit a-1 & $2.42 \mathrm{E}-07$ & 0.59 \\
\hline 755519908 & Phospholemman X1 & $1.30 \mathrm{E}-07$ & 0.61 \\
\hline 23957686 & Neuronal membrane glycoprotein M6-a1 & $5.49 \mathrm{E}-06$ & 0.61 \\
\hline 209863008 & V-type proton ATPase $116 \mathrm{kDa}$ subunit a3 & $1.16 \mathrm{E}-03$ & 0.61 \\
\hline 498752597 & Hemoglobin subunit $\beta-1$ & $2.12 \mathrm{E}-04$ & 0.62 \\
\hline 357588427 & a-1-antitrypsin 1-12 & $8.64 \mathrm{E}-05$ & 0.63 \\
\hline 91598783 & Solute carrier family 28 member 3 & $7.64 \mathrm{E}-07$ & 0.64 \\
\hline 6681095 & Cytochrome c & $1.70 \mathrm{E}-05$ & 0.64 \\
\hline 22094075 & ADP/ATP translocase 2 & $1.13 \mathrm{E}-07$ & 0.65 \\
\hline 6680710 & Aquaporin-1 & $7.69 \mathrm{E}-05$ & 0.67 \\
\hline 6678085 & Alpha-1-antitrypsin 1-4 & $2.29 \mathrm{E}-06$ & 0.68 \\
\hline 16716343 & Cytochrome c oxidase subunit $6 \mathrm{C}$ & $2.09 E-06$ & 0.69 \\
\hline 33563266 & Cytochrome c oxidase subunit NDUFA4 & $1.46 \mathrm{E}-06$ & 0.71 \\
\hline 20330802 & Serotransferrin precursor & $5.53 \mathrm{E}-07$ & 0.70 \\
\hline 226958351 & Sodium/potassium-transporting ATPase subunit a-4 & 4.40E-07 & 0.70 \\
\hline
\end{tabular}

where immunofluorescence microscopy seems to overestimate the change in protein abundance. The discrepancy might arise from poor recognition of a cytoplasmic pool of the protein that would be detected by both mass spectrometry and immunoblotting, such as phosphorylated forms of the protein. Despite discrepancies for a few proteins, there seems to be an acceptable correlation among the changes in abundance using the three techniques (Additional file 2: Figure S2).

\section{Enzymes involved in energy metabolism are prominently affected by Ncbe ko}

Numerous proteins involved in cellular metabolism have significantly altered abundance in Ncbe ko vs. Ncbe wt CP. Figure $3 \mathrm{a}$ shows the relative abundances of groups of proteins relating to the indicated metabolic pathways. Phosphofructokinase is the rate-limiting step in the glycolysis and all three isoforms detected in CPs have higher abundance in Ncbe ko than Ncbe wt, although the platelet form did not pass the $1 \%$ false discovery rate cut-off (Additional file 3: Figure S3). Immunoblotting determined that both the muscle and the neuronal type of the enzyme have higher abundance in Ncbe ko than Ncbe wt (not shown). In contrast to the proposed difference in capacity for respiratory ATP synthesis, thus, the capacity for glycolytic ATP synthesis seems conserved in the Ncbe ko CP.
A large number of mitochondrial enzymes are decreased in abundance in the CP of Ncbe ko mice compared to Ncbe wt. Additional file 4: Figure S4 and Additional file 5: Figure S5 compares the protein levels of detected enzymes related to the citric acid cycle and oxidative phosphorylation in Ncbe ko and Ncbe wt mice, respectively. The pyruvate dehydrogenases and with very few exceptions the entire range of enzymes in the citric acid cycle are uniformly decreased in abundance in the Ncbe ko (Additional file 4: Figure S4). For comparison, the cytoplasmic malate dehydrogenase was increased rather that decreased as opposed to the mitochondrial form. Most detected polypeptides belonging to the complex I and all of the proteins of complexes II, III, and IV of the respiratory chain were also uniformly decreased in abundance in Ncbe ko CP (Additional file 5: Figure $\mathrm{S} 5 \mathrm{~A}, \mathrm{~B})$. On average, the protein with the greatest difference in abundance in Ncbe ko compared to Ncbe wt is cytochrome $\mathrm{C}$. The lower abundance of this cytochrome in Ncbe ko CPECs was confirmed by immunofluorescence microscopy (Fig. 3b, c) and immunoblot analysis (Fig. 3d). Comparative analysis among the three different techniques in shown in Fig. 3e, where the agreement among the techniques is high $(\mathrm{p}=0.0001$ for immunoblotting and $\mathrm{p}=0.0329$ for immunofluorescence microscopy, $\mathrm{n}=5$ ). 
Table 3 Proteins with highest relative abundance in CP from Ncbe ko compared to Ncbe wt mice

\begin{tabular}{|c|c|c|c|}
\hline Accession & Description & p-value & Ratio \\
\hline 164565419 & $\begin{array}{l}\text { Carcinoembryonic antigen CAM } 2 \\
\text { (Ceacam-2) }\end{array}$ & $2.32 \mathrm{E}-05$ & 1.94 \\
\hline 6755592 & ү-synuclein & $1.08 \mathrm{E}-03$ & 1.88 \\
\hline 8393534 & $\begin{array}{l}\text { Non-histone chromosomal protein } \\
\text { HMG-17 }\end{array}$ & $6.57 \mathrm{E}-06$ & 1.83 \\
\hline 6679227 & Purkinje cell protein 4 & $1.66 \mathrm{E}-04$ & 1.82 \\
\hline 31542956 & Ubiquitin-conjugating enzyme E2 K 1 & $3.02 \mathrm{E}-05$ & 1.76 \\
\hline 145699099 & UDP-glucuronosyltransferase 1-1 & $6.49 \mathrm{E}-05$ & 1.73 \\
\hline 27734986 & $\begin{array}{l}\text { Putative adenosylhomocysteinase } 2 \\
\text { (IRBIT) }\end{array}$ & $1.01 \mathrm{E}-07$ & 1.71 \\
\hline 84000448 & Glial fibrillary acidic protein 2 & $3.26 \mathrm{E}-03$ & 1.70 \\
\hline 568963419 & Serine/threonine-protein kinase OSR1 & $2.40 \mathrm{E}-03$ & 1.65 \\
\hline 569018439 & $\begin{array}{l}\text { Prostaglandin F2 receptor negative } \\
\text { regulator }\end{array}$ & $5.92 \mathrm{E}-07$ & 1.58 \\
\hline 24418919 & Glycogen phosphorylase, brain form & $4.75 \mathrm{E}-05$ & 1.56 \\
\hline 124486606 & Predicted gene 12657 & $2.66 \mathrm{E}-05$ & 1.55 \\
\hline 257900524 & MAGUK p55 subfamily member 6 & $1.78 \mathrm{E}-05$ & 1.53 \\
\hline 84042521 & Barrier-to-autointegration factor & $1.19 E-06$ & 1.52 \\
\hline 569010320 & Disks large homolog 3 & $2.40 \mathrm{E}-04$ & 1.52 \\
\hline 10048452 & Monocarboxylate transporter 3 & $1.59 \mathrm{E}-04$ & 1.49 \\
\hline 161353454 & CD151 antigen & $1.11 \mathrm{E}-05$ & 1.49 \\
\hline 6680359 & Interferon gamma inducible protein 47 & $1.07 \mathrm{E}-04$ & 1.49 \\
\hline 166235890 & $\begin{array}{l}\text { Pro-cathepsin } \mathrm{H} \text { isoform } 1 \text { prepropro- } \\
\text { tein }\end{array}$ & $6.30 \mathrm{E}-07$ & 1.45 \\
\hline 568935961 & Septin-11 isoform X1 & $2.42 \mathrm{E}-03$ & 1.44 \\
\hline
\end{tabular}

The accession numbers are shown along with the protein names (description and common abbreviation), the t-test results, and the abundance ratio Ncbe ko/ Ncbe wt

The abundances of specific enzymes involved in glycogen metabolism are shown in Additional file 3: Figure S3B. Glycogen phosphorylase is a member of the metabolic enzymes with the highest abundance in Ncbe ko compared to Ncbe wt (Fig. 3f, $p=0.009876 ; n=5$ ). Three isoforms of the enzyme were identified in the $\mathrm{CP}$, with the brain type glycogen phosphorylase in Ncbe ko mice increased as assessed by both mass spectrometry and immunoblotting (Fig. 3g). The abundance of enzymes involved in glycogen synthesis, such as glycogen synthase, are also elevated in Ncbe ko mice (Additional file 3: Figure S3B). Thus, the capacities for both synthesis and breakdown of glycogen is likely increased in the Ncbe ko mouse model. Additional file 3: Figure S3C shows that enzymes of fatty acid metabolism are generally decreased in abundance in the Ncbe ko CP compared to Ncbe wt, while the four detected enzymes involved in amino acid metabolism are increased in abundance in Ncbe ko (Additional file 3: Figure S3D).

Numerous subunits of the ATP synthase complex were detected by mass spectrometry (Additional file 6: Figure
S6A). Except for one, all of these proteins are lower in abundance in CP isolated from Ncbe ko mice relative to Ncbe wt. Thus, the cellular capacity for mitochondrial ATP synthesis seems decreased in CPECs from Ncbe ko compared to Ncbe wt mice. The more variable decrease in enzymes of the citric acid cycle compared to the respiratory chain and ATP synthase may reflect their participation in a variety of other metabolic pathways other than oxidative phosphorylation.

Many molecular pathways are involved in transcriptional regulation of cellular metabolic activities. We assessed the expression levels of three of such pathways by immunoblotting (Fig. $4 \mathrm{a}-\mathrm{c}$ ) and compared the results to those obtained by mass spectrometry data (Fig. 4d). Peroxisome proliferator-activated receptor $\gamma$ coactivator $1 \alpha(\mathrm{PGC}-1 \alpha)$ is a transcriptional coactivator in mitochondrial biogenesis and oxidative metabolism that is highly sensitive to the energy status of the cell and under the control of the AMP-activated protein kinase (AMPK) [19]. PGC-1 $\alpha$ abundance was unchanged with both mass spectrometry and immunoblotting (Fig. 4a, d, for immunoblotting $\mathrm{p}=0.6472, \mathrm{n}=5$ ), indicating that CPECs from Ncbe ko mice. Indeed, the negative regulator of PGC- $1 \alpha$, sirtuin-2 display a tendency towards a higher abundance in Ncbe ko cells compared to Ncbe wt by mass spectrometry (Fig. 4e). The carcino-embryonic antigen-related cell adhesion molecule 2 (Ceacam-2) has been linked to a decrease in energy use at the organism level [20,21], and is almost doubled in abundance in Ncbe ko CP compared to Ncbe wt (Fig. 4e).

Mitochondrial $\mathrm{Tu}$ translation elongation factor (TUFM) is a key factor in translation of mitochondrial DNA, thereby playing an important role in the control of mitochondrial function [22]. TUFM abundance was slightly decreased in Ncbe ko CP compared to Ncbe wt as assessed by mass spectrometry, but was more than halved in abundance as assessed by immunoblotting (Fig. $4 \mathrm{~b}, \mathrm{~d}$, for immunoblotting $\mathrm{p}=0.0001, \mathrm{n}=5$ ). This may indicate a lower degree of mitochondrial synthesis in Ncbe ko than in Ncbe wt CP.

The cellular insulator protein, CCCTC-binding factor (CTCF) is a key regulator of nuclear chromatin structure and a transcriptional repressor [23]. It interacts with the general transcription factor II-I (GTF II-I), which serves various roles in transcription and signal transduction, such as directing CTCF to the promoter proximal regulatory regions of genes involved in metabolism. Although CTCF abundance was not statistical significantly changed by immunoblotting (Fig. 4c, $\mathrm{p}=0.532$, $\mathrm{n}=5$ ), both CTCF and GTF II-I levels are higher in Ncbe ko CP than in Ncbe wt by mass spectrometry (Fig. 4d, e). Thus, further studies are needed to discern whether the 


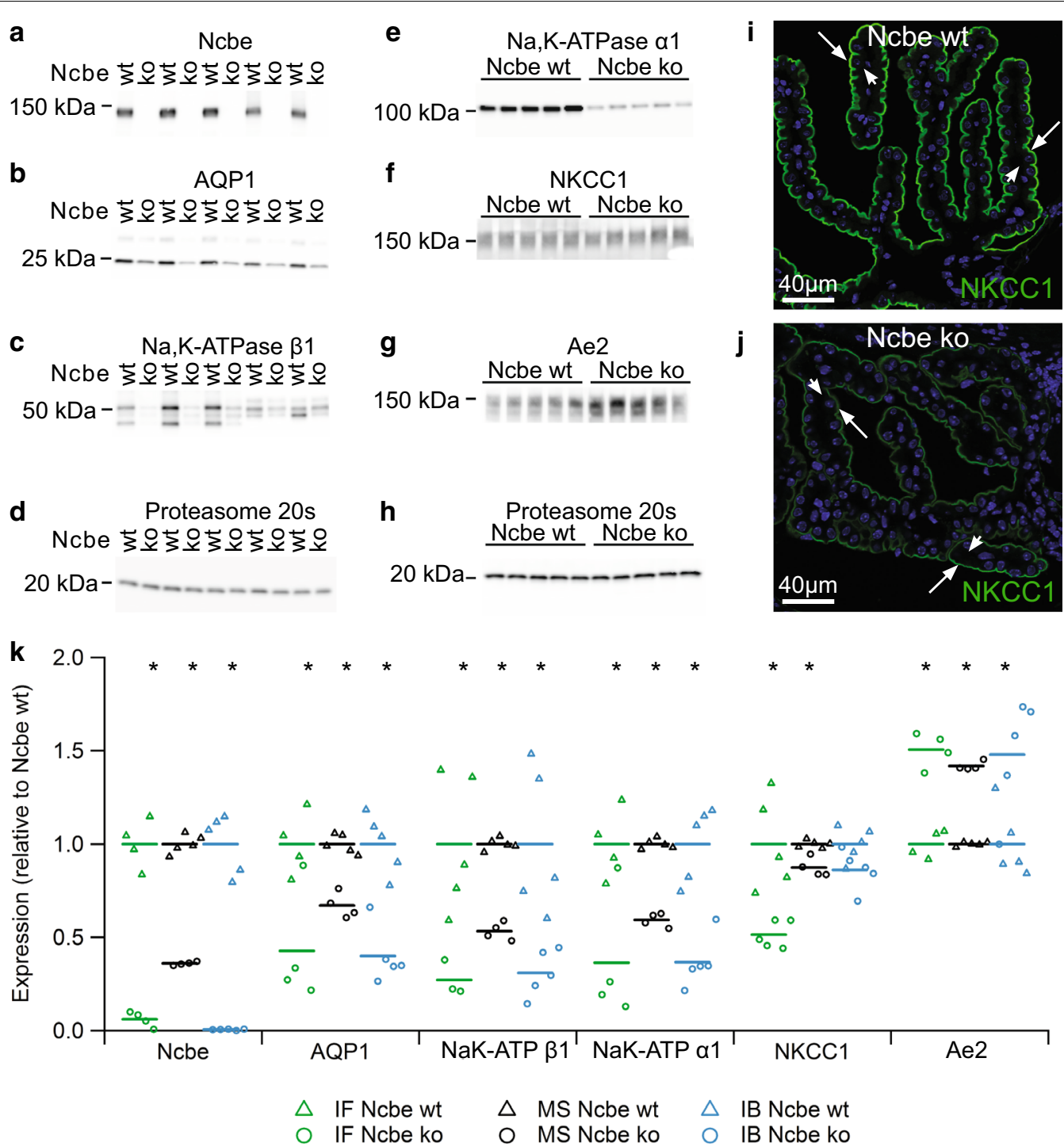

Fig. 2 Analysis of plasma membrane transporter expression. Immunoblot analysis of the protein abundance in the CP from Ncbe wt and Ncbe ko mice for a Ncbe, b AQP1, c Na,K-ATPase $\beta 1$ subunit, d Proteasome $20 \mathrm{~s}$, e Na,K-ATPase a1 subunit, f NKCC1, g Ae2, and h Proteasome 20 s. Immunofluorescence histochemistry was applied to compare protein expression of NKCC1 (green) in the IVth ventricle CP from i Ncbe wt and j Ncbe ko mice. Arrows indicate the luminal plasma membrane, while arrowheads indicate the basolateral membrane labyrinth. Nuclei are stained blue. $\mathbf{k}$ Scatter plot comparing the relative changes in transporter protein abundance obtained by immunofluorescence microscopy (IF), proteomic mass spectrometry analysis (MS), and immunoblotting $(\mathrm{IB})\left({ }^{*} p<0.05, n=5\right)$. Mean values are normalized to control (Ncbe wt) and indicated by horizontal bars. Triangles indicate data points from Ncbe wt CP, whereas circles represent data from Ncbe ko CP. Mean data for the IF semi-quantitation, except for NKCC1 are from previous publications [13-15]

observed decrease in energy metabolic enzymes are governed by the CTCF/GTF II-I system.

\section{The CP ATP level is elevated in Ncbe ko mice}

The simplest explanation for the general decrease in mitochondrial enzymes would be a decline in number or-more precisely-the cellular volume of mitochondria in CPECs in Ncbe ko mice compared to Ncbe wt. The predominantly decreased abundance of mitochondrial translocating proteins (Additional file 6: Figure S6B) and the specific decrease in mitochondrial (or type B) vs. cytoplasmic (or type A) cytochrome b5 (Additional file 6: Figure S6C) in CPECs from Ncbe ko mice provide support for this notion. Figure 5a shows the estimated mitochondrial area per cell as assessed by the cytochrome $\mathrm{C}$ immunofluorescence signal. The analysis revealed a decrease in cellular mitochondrial area to approximately $65 \%(\mathrm{p}=0.0073, \mathrm{n}=5$, 
Fig. 3 Protein abundance of proteins in selected metabolic pathways. a Scatter plot showing the relative changes in abundance between Ncbe wt and Ncbe ko CP among proteins involved in the glycolysis, glycogen, amino acid, and fatty acid metabolism, the tricarboxylic acid (TCA) cycle, respiratory chain, subunits of the ATP synthase, redox enzymes and mitochondrial transport proteins $\left({ }^{*} p>0.05, n=5\right)$. Mean values are normalized to control (Ncbe wt) and indicated by horizontal bars. Triangles indicate data point from Ncbe wt CP, whereas circles represent data from Ncbe ko CP. b, c Representative immunofluorescence micrographs comparing the protein expression of cytochrome C (green) in Ncbe wt and Ncbe ko 4 th ventricle $C P$, respectively. Nuclei are stained blue. $\mathbf{d}$ Immunoblot analysis of cytochrome $\mathrm{C}$ protein abundance in the $\mathrm{CP}$ from $\mathrm{Ncbe}$ wt and Ncbe ko mice. e Scatter plot comparing relative changes in cytochrome $\mathrm{C}$ protein abundance obtained by immunofluorescence microscopy (IF), proteomic mass spectrometry analysis (MS), and immunoblotting (IB) $\left({ }^{*} p<0.05, n=5\right)$. Mean values are normalized to control (Ncbe wt) and indicated by horizontal bars. Triangles indicate data points from Ncbe wt CP, whereas circles represent data from Ncbe ko CP. $\mathbf{f}$ Immunoblot analysis of glycogen phosphorylase (brain type) protein abundance in the CP from Ncbe wt and Ncbe ko mice. g Scatter plot comparing relative changes in glycogen phosphorylase abundance obtained by proteomic mass spectrometry analysis (MS), and immunoblotting (IB) $\left({ }^{*} p<0.05, n=5\right)$. Mean values are normalized to control (Ncbe wt) and indicated by horizontal bars. Triangles indicate data points from Ncbe wt CP, whereas circles represent data from Ncbe ko CP with a total of 482 Ncbe wt cells and 364 Ncbe ko cells assessed) in Ncbe ko CPECs compared to Ncbe wt CPECs. The cellular cytochrome $\mathrm{C}$ intensity in the Ncbe ko CPECs cells amounted to approximately 59\% of the Ncbe wt values in the same analysis (Fig. 5b, $\mathrm{p}=0.0051, \mathrm{n}=5$ ). Thus, both the mitochondrial volume and cytochrome $\mathrm{C}$ intensity seems decreased in CPECs from Ncbe ko compared to Ncbe wt. The average area of the epithelial cells from Ncbe ko mice amounted to approximately $78 \%$ of the area of CPECs from Ncbe wt mice as assessed from the background fluorescence
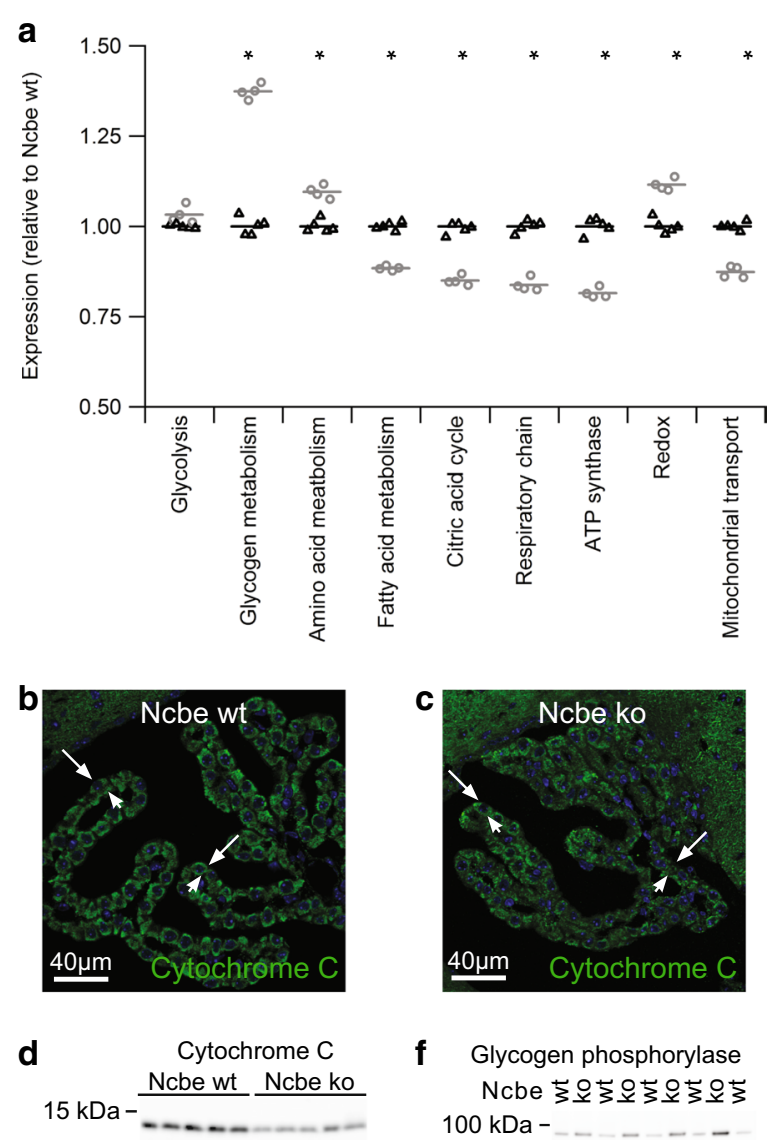

f Glycogen phosphorylase

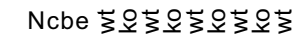
$100 \mathrm{kDa}-$ $75 \mathrm{kDa}-$

\section{e}
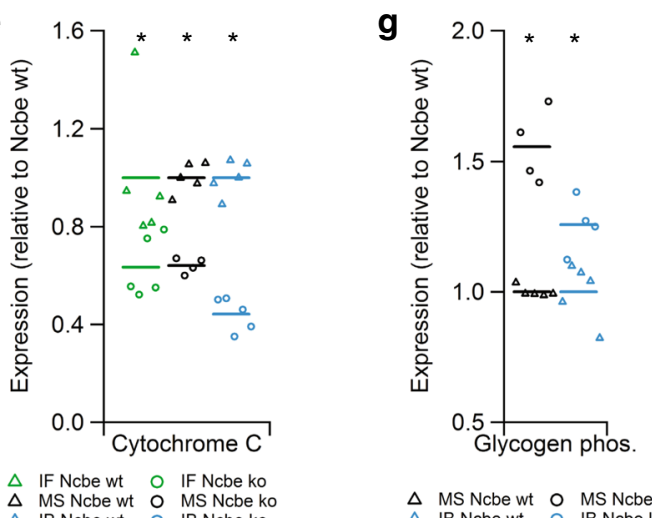

$\triangle$ MS Ncbe wt $\bigcirc$ MS Ncbe ko $\triangle$ IB Ncbe wt $O$ IB Ncbe ko

micrographs of the CP (Fig. $5 \mathrm{c}, \mathrm{p}=0.0028, \mathrm{n}=5$, with a total of 1214 Ncbe wt cells and 1222 Ncbe ko cells assessed). This is equivalent to a decrease to $69 \%$ in estimated cell volume from 2611 to $1794 \mu^{3}$. Taking the smaller cell size in Ncbe ko mice into account, the mitochondrial area in the CPECs is reduced to $83 \%$ of the Ncbe wt cells, which does not reach statistical significance $(\mathrm{p}=0.1982, \mathrm{n}=5)$. 


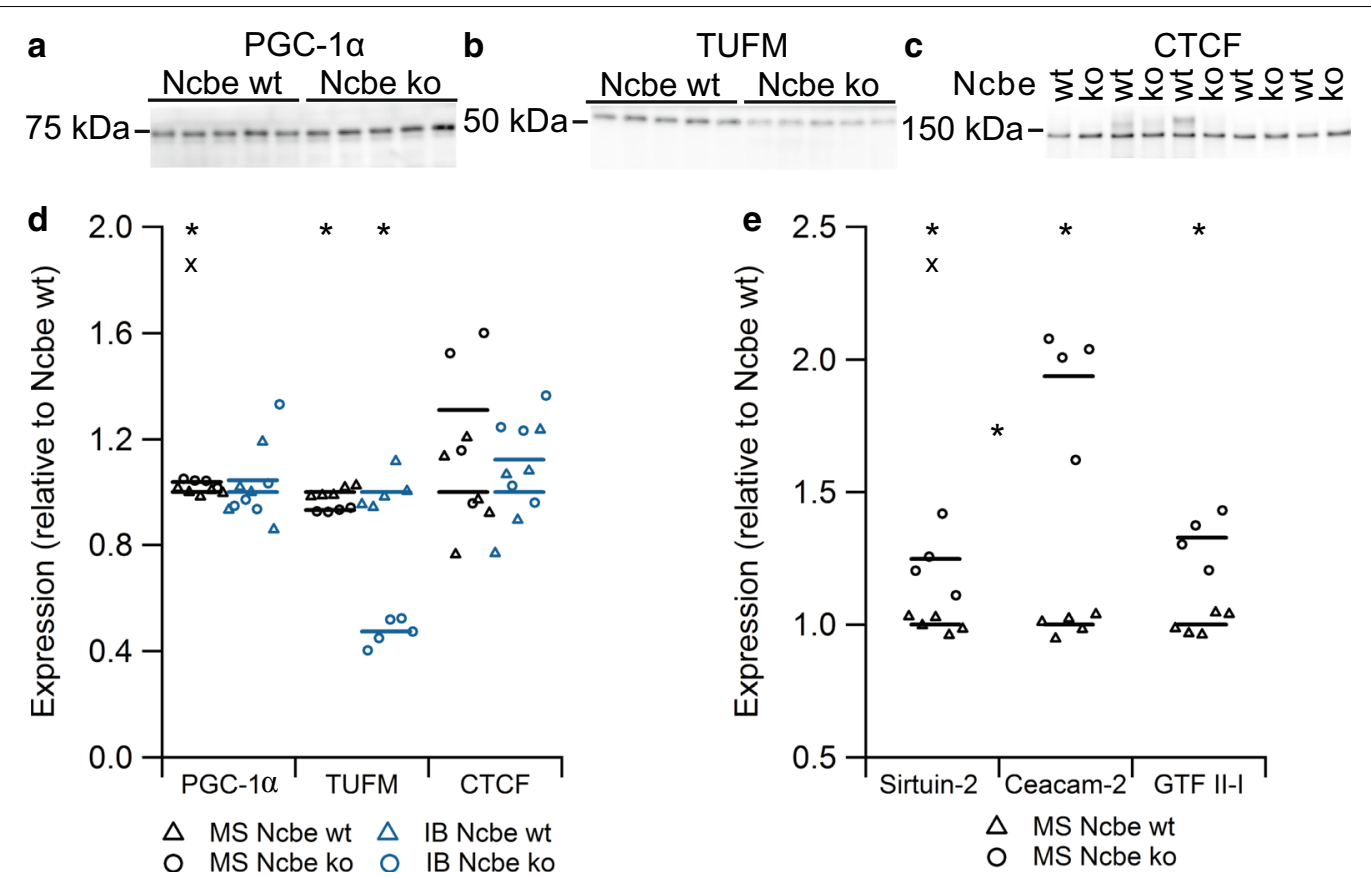

Fig. 4 Analysis of the relative expression of proteins involved in the regulation of energy metabolic pathways. Immunoblot analysis of the protein abundance in the CP from Ncbe wt and Ncbe ko mice for a PGC-1 a, b TUFM, and c CTCF. $\mathbf{d}$ Scatter plot comparing relative changes in protein abundance obtained by proteomic mass spectrometry analysis (MS), and immunoblotting (IB) $\left({ }^{*} p<0.05, X\right.$ : Failed FDR of $\left.1 \%, n=5\right)$. Mean values are normalized to control (Ncbe wt) and indicated by horizontal bars. Triangles indicate data point from Ncbe wt CP, whereas circles represent data from Ncbe ko CP. e Scatter plot showing the comparative mass spectrometry analysis of additional regulatory proteins Sirtuin-2, Ceacam-2 and general transcription factor II-I between Ncbe wt and Ncbe ko CP $\left({ }^{*} p<0.05, X\right.$ : Failed FDR of 1\%, $\left.n=5\right)$. Mean values are normalized to control (Ncbe wt) and indicated by horizontal bars. Triangles indicate data points from Ncbe wt CP, whereas circles represent data from Ncbe ko CP

The cellular ATP levels in Ncbe wt and Ncbe ko CP were compared in order to assess the consequences of the potential decreased cellular capacity for ATP synthesis. Figure $5 \mathrm{~d}$ shows that the Ncbe ko $\mathrm{CP}$ has higher ATP levels compared to the Ncbe wt tissue $(\mathrm{p}=0.0060, \mathrm{n}=6)$. Thus, the $\mathrm{Na}^{+}, \mathrm{K}^{+}$-ATPase expression does not seem to be reduced by low intracellular ATP in the Ncbe ko CP. Low $\mathrm{d} \mathrm{Na}^{+}, \mathrm{K}^{+}$-ATPase expression most likely leads to reduced transport activity resulting in a low intracellular $\mathrm{K}^{+}$content. Indeed, the tissue $\mathrm{K}^{+}$content (normally, $97 \%$ of $\mathrm{K}^{+}$is intracellular) was significantly reduced in Ncbe ko compared to Ncbe wt (Fig. 5e, $\mathrm{p}=0.0092, \mathrm{n}=4$ ), suggesting that less $\mathrm{K}^{+}$is pumped into the cells despite sufficient ATP levels. Thus, the CPECs from Ncbe ko mice appear to maintain a smaller cell volume based on reduced ion transport, but do not lack ATP to drive these processes.

\section{Altered regulators of ion transporter function in $\mathrm{CP}$ from Ncbe ko mice}

The "IP3R Binding protein released with Inositol 1,4,5-Trisphosphate"/"Protein Phosphatase-1" (IRBIT/ PP1) pathway and the With-No lysine (K)" "SPS1related Proline/Alanine-rich Kinase"/“Oxidative
Stress-Responsive kinase 1" (WNK/SPAK/OSR1) pathway are important modulators of the cellular ion transporter regulation that likely influence each other at a cellular level [24, 25].

OSR1 was also in the top-20 percent of proteins with higher abundance in Ncbe ko vs. Ncbe wt CP by mass spectrometry (Table 3, Fig. 6a), while SPAK in Ncbe ko was not significantly changed compared to Ncbe wt CP. However, SPAK was identified in Ncbe co-IP experiments (Additional file 7: Table S1). Antibodies against the phosphorylated OSR1/SPAK (pOSR1 and PSPAK) localized the protein to the luminal membrane domain of CPECs, suggesting a primary function of the active kinase in regulating luminal membrane transporters (Fig. 6b). The staining pattern was conserved in Ncbe wt CP (Fig. 6c). Immunoblot analysis using the common pOSR $1 / \mathrm{pSPAK}$ antibody indicates that the abundance of pOSR1 (75 kDa band, pSPAK/pOSR1 (M)-antibody) is lower in Ncbe ko than Ncbe wt CP (Fig. 6d, $\mathrm{p}=0.02947, \mathrm{n}=5$ ). The decrease in abundance of the higher band representing pSPAK in Ncbe ko $\mathrm{CP}$ did not reach statistical significance $(\mathrm{p}=0.05899$, $\mathrm{n}=5$ ), similar to the $65 \%$ decrease in immunofluorescence microscopy signal with the same antibody in 

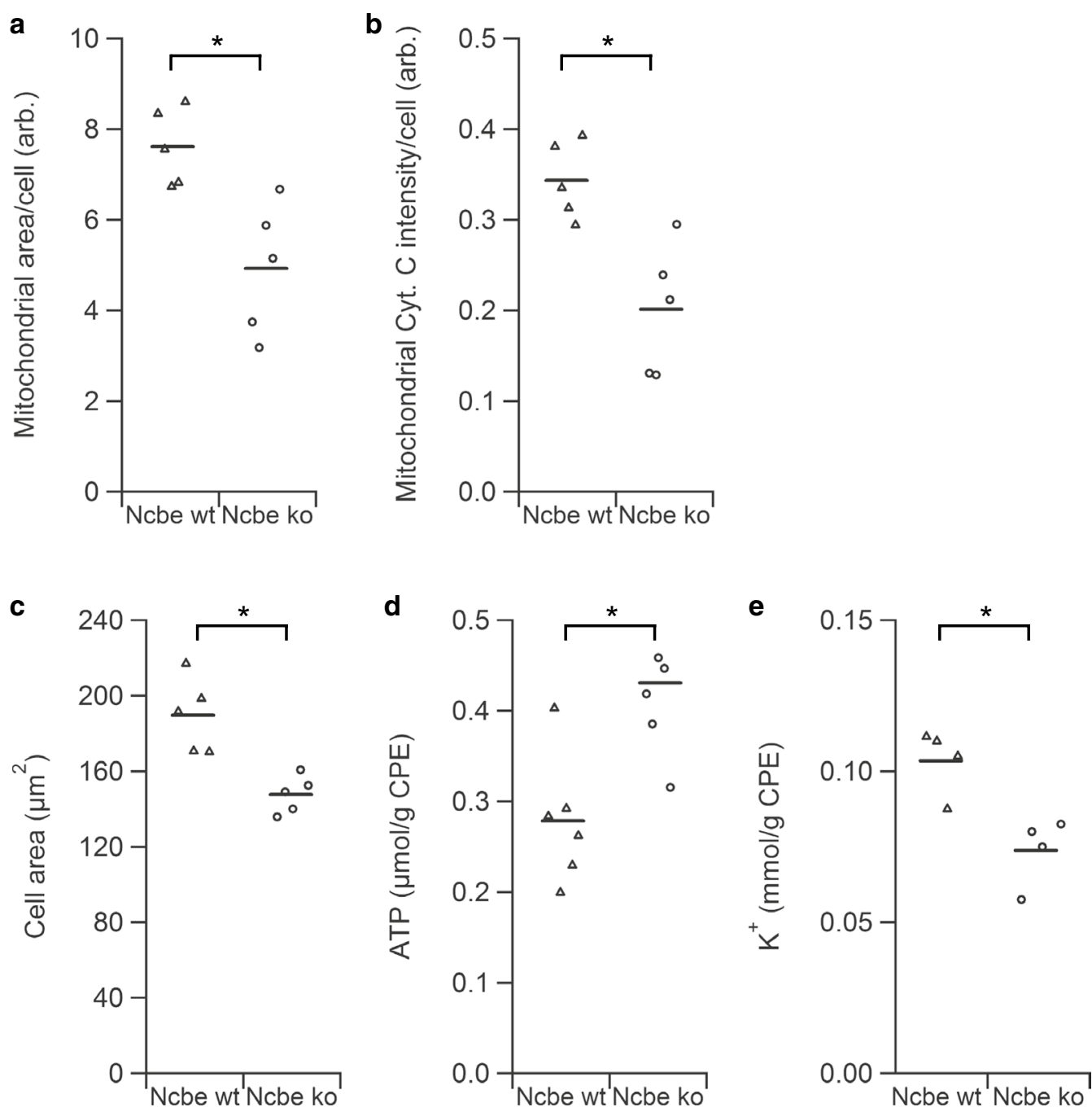

Fig. 5 Evaluation of mitochondrial abundance, cell size, ATP, and $\mathrm{K}^{+}$levels. a Scatter plot comparing the average mitochondrial area determined by the cytochrome C positive area within cells from Ncbe wt and Ncbe ko CP $\left({ }^{*} p<0.05, n=5\right.$, representing 364 Ncbe wt cells and 482 Ncbe ko cells). Mean values indicated by horizontal bars. Triangles indicate data points from Ncbe wt CP, whereas circles represent data from Ncbe ko CP. b The mean cytochrome C immunostaining intensity per cell from the Ncbe wt and Ncbe ko CP epithelium, respectively $\left({ }^{*} p<0.05, n=5\right.$, representing 364 Ncbe wt cells and 482 Ncbe ko cells). Mean values indicated by horizontal bars. Triangles indicate data points from Ncbe wt CP, whereas circles represent data from Ncbe ko CP. c Estimation of the average cell size in Ncbe wt and Ncbe ko CP epithelium from micrographs of background fluorescence ${ }^{*} p<0.05, n=5$, representing 1214 Ncbe wt cells and 1222 Ncbe ko cells). Mean values indicated by horizontal bars. Triangles indicate data points from Ncbe wt CP, whereas circles represent data from Ncbe ko CP. $\mathbf{d}$ Scatter plot showing the mean ATP levels in the CP from Ncbe wt and Ncbe ko mice by chemiluminescence $\left.{ }^{*} \mathrm{p}<0.05, n=6\right)$. Mean values indicated by horizontal bars. Triangles indicate data points from Ncbe wt CP, whereas circles represent data from Ncbe ko CP. e Estimation of the mean cellular $\mathrm{K}^{+}$content in the CP from Ncbe wt and Ncbe ko mice by flame photometry $\left.{ }^{*} \mathrm{p}<0.05, n=4\right)$. Mean values indicated by horizontal bars. Triangles indicate data points from Ncbe wt $C P$, whereas circles represent data from Ncbe ko CP

Ncbe ko tissue (not shown, $\mathrm{p}=0.2092$ ). Immunoblotting with a separate antibody [pOSR1 (S)-antibody] that only seem to recognize pOSR1 revealed a similar decrease in POSR1 abundance in the Ncbe ko tissue (Fig. 6e, $p=0.008258, n=5$ ). Figure 6f illustrates the lower abundance of pOSR1/pSPAK with the same antibody, pSPAK/pOSR1(M), and pOSR1 with the separate antibody, OSR1(S), in the CP from Ncbe ko mice compared to Ncbe wt mice. Similar results were obtained with three sets of samples, each with $n=5$ for each genotype.

IRBIT was immunolocalized to the basolateral membrane domain of the CPECs, where it co-localized with Ncbe (Fig. 7a). IRBIT was also identified using mass 

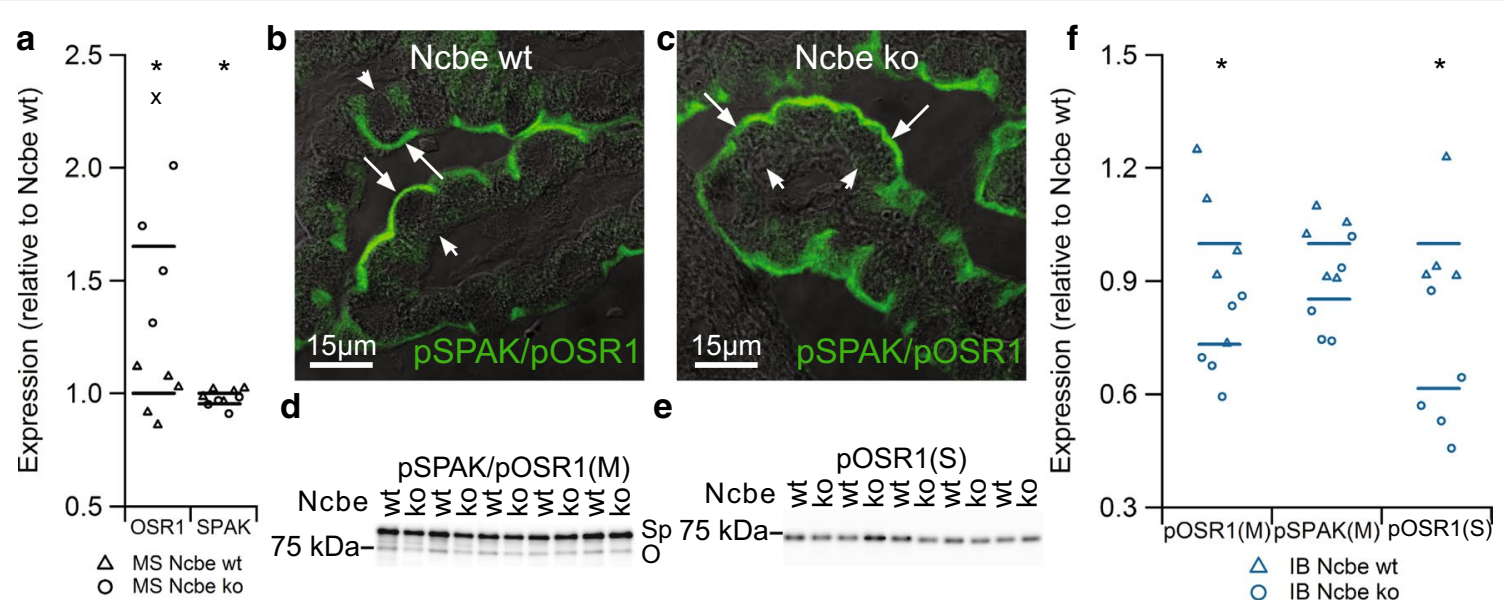

Fig. 6 Comparison of the expression of ion transport regulators OSR1 and SPAK in Ncbe wt and Ncbe ko mouse CP. a Scatter plot illustrating the difference in mean CP OSR1 and SPAK expression between Ncbe wt and Ncbe ko mice, as assessed by comparative mass spectrometry $\left(^{*} p<0.05\right.$, $X$ : Failed FDR of 1\%, $n=5$ ). Mean values are normalized to control (Ncbe $w t)$ and indicated by horizontal bars. Triangles indicate data points from Ncbe wt CP, whereas circles represent data from Ncbe ko CP. $\mathbf{b}$ Immunofluorescence micrograph showing the cellular distribution of pSPAK/pOSR1 (green) at high magnification of the CP from an Ncbe wt mouse. c A similar micrograph of pSPAK/pOSR1 staining in the CP from an Ncbe ko mouse. The fluorescence images are overlaid onto the corresponding differential interference contrast (DIC) images. Arrows indicate the luminal plasma membrane, while arrowheads indicate the basolateral membrane labyrinth. $\mathbf{d}$, e Immunoblot analysis of the pSPAK/pOSR1 abundance in the CP from Ncbe wt and Ncbe ko mice with two antibodies ("M" and "S", respectively). Sp indicates the expected migration of pSPAK, whereas O indicates the expected pOSR1 size. f Scatter plot comparing relative changes in POSR1 and pSPAK abundances obtained by immunoblotting (IB) with the two antibodies ( ${ }^{*} p<0.05, n=5$ ). Mean values are normalized to control (Ncbe wt) and indicated by horizontal bars. Triangles indicate data points from Ncbe wt CP, whereas circles represent data from Ncbe ko CP

spectrometry on Ncbe co-immunoprecipitations (co-IP) from CP samples (Additional file 7: Table S1), suggesting a role of IRBIT in regulating Ncbe. The subcellular distribution of IRBIT was similar in Ncbe wt and Ncbe ko CPECs (Fig. 7b, c). The IRBIT immunofluorescence signal and thereby relative abundance was higher in Ncbe ko CP, which was also observed by immunoblotting (Fig. 7d). Figure 7e compares the IRBIT abundance in Ncbe ko and Ncbe wt CP by semi-quantitative immunofluorescence, mass spectrometry, and immunoblotting. All three techniques revealed a robustly elevated IRBIT abundance in the Ncbe ko CP $(\mathrm{p}=0.01725$ for immunofluorescence microscopy and $\mathrm{p}=0.00865$ for immunoblotting, $n=5$ ). PLA assays were executed in order to confirm the close proximity of Ncbe and IRBIT first suggested by the double immunolabeling above. Indeed, positive PLA reaction occurred only in CPECs from Ncbe wt mice, whereas Ncbe ko CPECs were negative (Fig. $7 \mathrm{f}-\mathrm{i}$, $n=5$ ). The positive reaction products in Ncbe wt CPECs were mainly, but not exclusively observed in the basolateral membrane domain.

\section{Discussion}

In transporting epithelia, the removal of a central transport mechanism is expected to have a profound impact on the cellular state or function. In theory, the cells may adapt to the loss of transport activity by compensatory increases in the remaining or alternative transport pathways or the cells might switch to a more dormant state. In the $\mathrm{CP}, \mathrm{Ncbe}$ is likely the major $\mathrm{Na}^{+}$import mechanism to sustain transcellular salt and water movement for CSF secretion [2, 12, 26, 27]. Genetic disruption of Ncbe resulted in a reduced volume of the brain ventricles, which was paralleled by the decrease in the $\mathrm{Na}^{+}$-dependent $\mathrm{HCO}_{3}{ }^{-}$uptake in CPECs [12]. We reported that the abundance and membrane targeting of various proteins in the CPECs were affected by Ncbe ko $[13,15]$. Here, we provide a comprehensive overview of the observed cellular differences within the CP following Ncbe deletion. We provide a novel model for similar assessment in other transporting epithelia during disrupted $\mathrm{Na}^{+}$transport.

The mass spectrometry analysis was validated by comparing new and previously published data on plasma membrane transport proteins abundance in the $\mathrm{CP}$ from Ncbe ko and Ncbe wt mice obtained by two antibodybased techniques: immunofluorescence histochemistry and immunoblotting. There is a good general agreement among the three techniques, regardless of the fact that mass spectrometry and immunoblotting were performed on the whole $\mathrm{CP}$ tissues, whereas immunofluorescence histochemistry provided data specifically from CPECs. However, the performance of immunofluorescence histochemistry was more variable and therefore tends to 

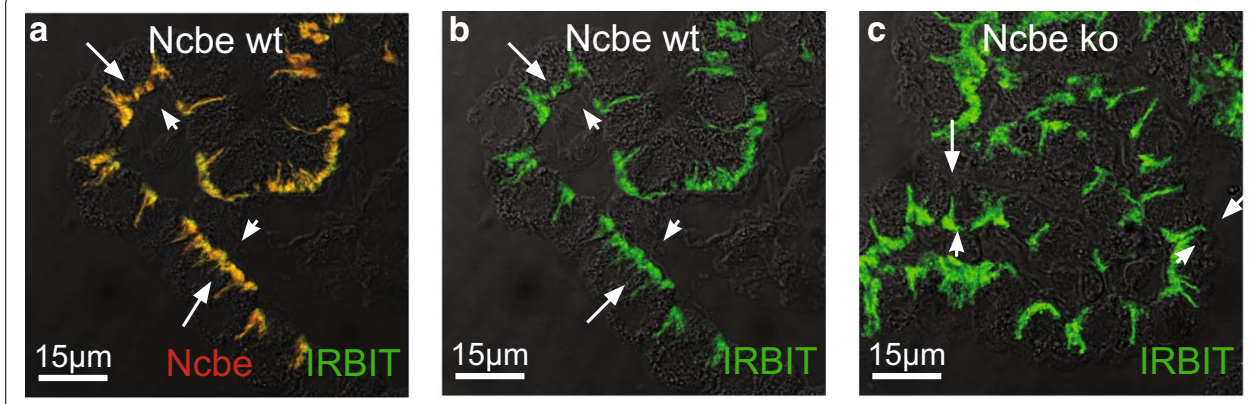

d

IRBIT

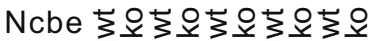

$75 \mathrm{kDa}-$
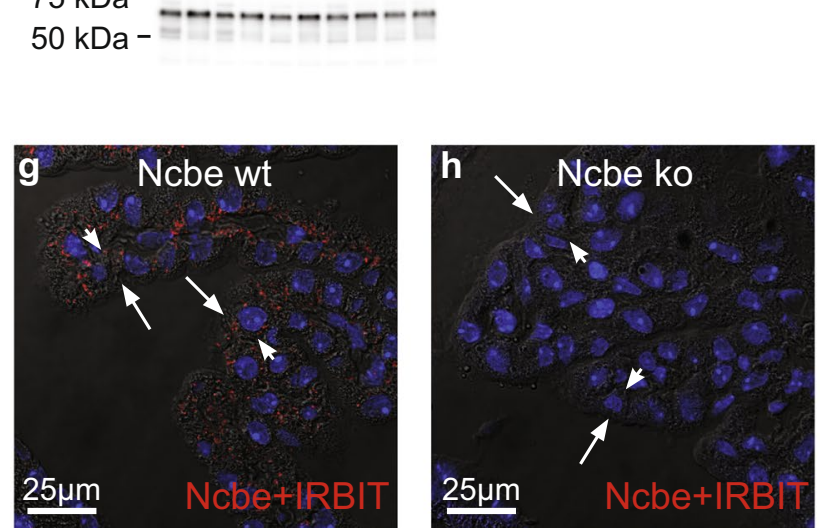
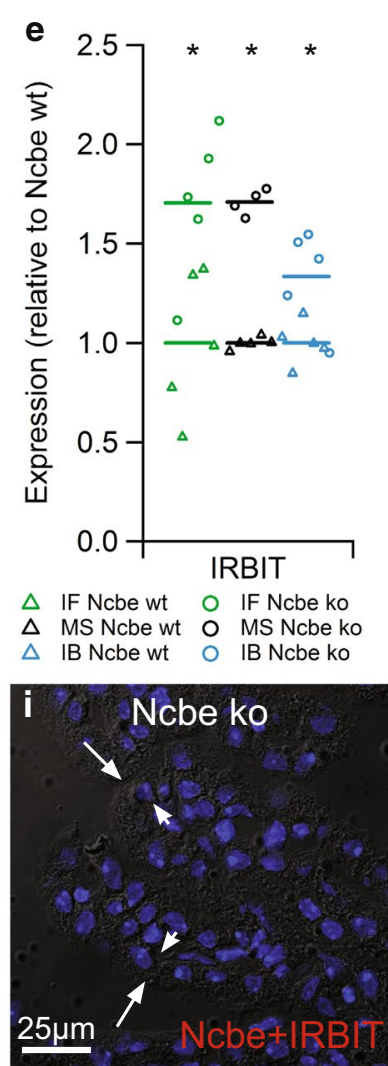

Fig. 7 Comparison of the expression of ion transport regulator IRBIT in Ncbe wt and Ncbe ko mouse CP. a Double immunofluorescence micrograph stained for Ncbe (red) and IRBIT (green) at high magnification of the CP from a Ncbe wt mouse. b The same micrograph showing only the anti-IRBIT immunoreactivity. c A similar micrograph of IRBIT staining in the CP from an Ncbe ko mouse. The fluorescence images are overlaid onto the corresponding DIC images. Arrows indicate the luminal plasma membrane, while arrowheads indicate the basolateral membrane labyrinth. $\mathbf{d}$ Immunoblot analysis of the IRBIT abundance in the CP from Ncbe wt and Ncbe ko mice. e Scatter plot comparing relative changes in IRBIT abundance obtained by immunofluorescence microscopy (IF), proteomic mass spectrometry analysis (MS), and immunoblotting (IB) $\left(^{*} \mathrm{p}<0.05\right.$, $n=5$ ). Mean values are normalized to control (Ncbe wt) and indicated by horizontal bars. Triangles indicate data points from Ncbe wt CP, whereas circles represent data from Ncbe ko CP. f, g Representative images resulting from PLA assays using anti-Ncbe and anti-IRBIT antibodies on Ncbe wt CP. h, i Similar representative images using the same antibodies on Ncbe ko CP (run in parallel). Positive reaction products are shown in red. Nuclei are shown in blue and the fluorescence signals are overlaid onto the corresponding DIC image

decrease the correlation coefficient in comparisons with this technique. This seems to be caused by antibody performance rather than the specific epithelial information, as the connective tissue and blood vessels produced only negligible signal by this technique. Go-term analysis of our mass spectrometry data indicated that a large fraction of proteins with altered abundance in Ncbe ko CP compared to Ncbe wt CP are involved in metabolic activity. Closer analysis of the involved metabolic pathways, such as glycolysis, citric acid cycle, and oxidative phosphorylation, strongly suggested that the cellular capacity for ATP synthesis is systematically reduced in Ncbe ko compared to Ncbe wt CP. By contrast, the capacity for glycogen metabolism is likely enhanced. We confirmed altered abundance of the two enzymes with the largest deviations between the two genotypes with respect to metabolism: glycogen phosphorylase and cytochrome C.
Plausibly, the current data indicate two opposite explanatory mechanisms in the Ncbe CPECs; (1) metabolic changes in Ncbe ko CP, such as the decreased capacity for ATP synthesis, induce changes in membrane transporter expression, or (2) decreased ion transport activity changes metabolic activity in CPECs. The first possibility seems to be ruled out by both the elevated ATP level, as well as the pattern of transcriptional regulators of metabolism including PGC-1 and Sirtuin-2 in Ncbe ko CP. The changes in protein abundance for CTCF/GTF II-II could be interpreted as a compensatory reaction to an apparent decreased capacity for respiratory ATP synthesis, while the TUFM level in the CP from Ncbe ko mice is in accordance with a lower level of mitochondrial biogenesis.

The second hypothesis suggests that the lower abundance of mitochondrial enzymes involved in ATP 
generation in the Ncbe ko $\mathrm{CP}$ is a reaction to lower energy consumption and elevated ATP levels-a Warburg effect-like pattern. Several separate lines of evidence point to low transport activity as the primary signal in cellular protein expression. Firstly, CPECs from Ncbe ko mice are smaller than Ncbe wt cells and the tissue $\mathrm{K}^{+}$ content is reduced significantly in Ncbe ko cells despite sufficient ATP levels. This is consistent with previous reports of decreased secretion by $\mathrm{CP}$ in conditions such as ageing, where decreased cell size, lower $\mathrm{K}^{+}$contents, elevated ATP levels are also observed [28, 29]. Secondly, proteins from two major systems regulating ion transport function have changed protein abundance in Ncbe ko CPECs compared to Ncbe wt CPECs: IRBIT and OSR1. IRBIT is a $\mathrm{Ca}^{2+} / \mathrm{CaMKII}$ sensitive competitive inhibitor of the $\mathrm{IP}_{3}$ receptor involved in enhancing epithelial $\mathrm{HCO}_{3}{ }^{-}$transport through activation of mechanisms such as $\mathrm{Na}^{+}$-coupled $\mathrm{HCO}_{3}{ }^{-}$transporters $\mathrm{NBCe} 1, \mathrm{NBCn} 1$, and NDCBE, as well as NHE3, CFTR and slc26 derived ion transporters [24]. We found that IRBIT colocalizes with Ncbe in the basolateral membrane domain of the CPECs, that Ncbe co-immunoprecipitates IRBIT from the $\mathrm{CP}$, and that close association between the two proteins in CPECs could be confirmed by PLA assays. However, the regulation of Ncbe by IRBIT has not yet been investigated directly. $\mathrm{NBCn} 1$ is, like Ncbe and Ae2, expressed in the basolateral membrane domain in these cells. However, it is not thought to be involved in vectorial transport in this epithelium, as it is a luminal membrane protein in some rodents and areas of the human CP $[14,27,30]$. Thus, NBCn1 is not likely to be the main target for IRBIT in the CP epithelium. In Ncbe ko CP, IRBIT abundance is higher than in Ncbe wt, indicating an attempt to compensate for lower $\mathrm{HCO}_{3}{ }^{-}$transport capacity in the Ncbe ko. Indeed, this may result in the observed enhancement in Ae2 expression in Ncbe ko CP, as this transporter belongs to the same IRBIT regulated gene family of $\mathrm{HCO}_{3}{ }^{-}$transporters as $\mathrm{NBCe}$. As judged from the lower secretory activity (small cell volume, high ATP level, low $\mathrm{K}^{+}$level) and lower transport capacity of key ion transporters and the AQP1, the induction of basolateral Ae2 expression ( $\mathrm{Cl}^{-}$import) does not seem to compensate for Ncbe deletion in the secretory pathway.

The WNK-SPAK/OSR1 pathway regulates the functional activity of an array of transporters involved in epithelial absorption and secretion, such as NCC, NKCC1, ROMK, NBCe1, CFTR and slc26 derived anion transporters [24]. It may seem contradictory that the general OSR1 expression is higher in Ncbe ko CP than in the Ncbe wt tissue, while the phosphorylated (activated) form of OSR1 is lower in Ncbe ko. However, this also indicates a divergence of long-term regulation of OSR1 expression and short-term OSR1 regulation by phosphorylation. The resulting overall effect on OSR1 by genetic disruption of Ncbe seems to be a reduced activity. It may seem contradictory that Ncbe co-immunoprecipitated SPAK. Opposite Ncbe, the majority of SPAK is localized to luminal cell domains. However, minor amounts of SPAK may be distributed throughout the cytoplasm, as it is not membrane associated. This is actually indicated by immunofluorescence microscopy on higher intensity exposure (not shown). Also, protein interactions in co-IP assays might form after tissue homogenization and represent an artefact. Again, further PLA should be performed to solve this question.

The lack of $\mathrm{Na}^{+}$import by Ncbe in the ko model reduces cell size and decreases the influx of $\mathrm{Na}^{+}$for luminal extrusion by the $\mathrm{Na}^{+}, \mathrm{K}^{+}$-ATPase, $\mathrm{NBCe} 2$ and perhaps NKCC1. In turn, a lower pumping activity would lead to elevation of intracellular $\mathrm{K}^{+}$and lower ATP consumption. A reduction in cell size would normally activate WNK (increased phosphorylation due to reduced intracellular chloride), that should activate SPAK/OSR1 [24]. We did not detect WNKs in the current study, but have previously reported the expression of WNK1 in the CP [31].

The $\mathrm{Na}^{+}, \mathrm{K}^{+}$-ATPase subunits $\alpha 1, \beta 1$, and the accessory subunit phospholemman are the dominant subunits of the luminal pump complex in the CPECs [18]. These $\mathrm{Na}^{+}, \mathrm{K}^{+}$-ATPase subunits are among the proteins of lowest relative abundance in the Ncbe ko tissue by mass spectrometry analysis and thus more affected than other key transporters in the secretory process. Increased $\mathrm{Na}^{+}$-influx, cell swelling, $\left[\mathrm{Na}^{+}\right]_{\mathrm{i}}$ increase, $\left[\mathrm{K}^{+}\right]_{\mathrm{i}}$ decrease normally increases $\mathrm{Na}^{+}, \mathrm{K}^{+}$-ATPase transcription, surface abundance, and activity levels [32, 33]. While Ncbe ko CPECs appear to experience lower $\mathrm{Na}^{+}$-influx, cell shrinkage would tend to restrict $\mathrm{Na}^{+}, \mathrm{K}^{+}$-ATPase expression and activity, whereas the reduced intracellular $\mathrm{K}^{+}$ content would have the opposite effect. Thus, it would appear that the $\mathrm{Na}^{+}$influx per se or the cell shrinkage are the main mediators of reduced $\mathrm{Na}^{+}, \mathrm{K}^{+}$-ATPase expression in Ncbe ko CPECs. This is in accordance with other models of reduced transport by CPECs and cell size [8, $34,35]$. A mirror phenomenon was observed in cultured renal epithelial cells, where enhanced $\mathrm{Na}^{+}$influx increased $\mathrm{Na}^{+}, \mathrm{K}^{+}$-ATPase surface expression [36], indicating that posttranslational regulation exists in addition to the transcriptional control of the $\mathrm{Na}^{+}, \mathrm{K}^{+}$-ATPase. We hypothesize that the $\left.\left[\mathrm{Na}^{+}\right]_{i} / \mathrm{K}^{+}\right]_{\mathrm{i}}$ is the trigger for the reduced $\mathrm{Na}^{+}, \mathrm{K}^{+}$-ATPase expression in the CPECs from Ncbe ko mice.

The general pattern of differences in protein expression in Ncbe ko vs. Ncbe wt bears some resemblance to the core findings from transcriptomic and proteomic 
studies of conditions with putatively reduced cerebrospinal fluid secretion such as ageing and Alzheimer's disease. $\mathrm{Na}^{+}, \mathrm{K}^{+}$-ATPase and AQP1 expression levels are decreased in the $\mathrm{CP}$ from ageing rats [28], and the $\mathrm{CP}$ in ageing sheep has a reduced $\mathrm{Na}^{+}$uptake, high ATP content, and relative mitochondrial deficiency in addition to a low CSF secretion rate [29]. Similar to the current study, a data mining study of Alzheimer's disease data demonstrated a downregulated expression of NKCC1, Ncbe, $\mathrm{Na}^{+}, \mathrm{K}^{+}$-ATPase subunits (except for the $\alpha 1$ subunit), and ATP synthase subunits in the CP [37]. A transcriptome study of human Alzheimer's disease CP material documented a reduced expression of the corresponding transcripts [38]. It is interesting, that many of the changes observed in ageing and Alzheimer's disease resemble the Ncbe ko model with respect to these central features of the CP epithelium.

\section{Conclusion}

Disruption of Ncbe induces several alterations in cellular metabolism such as glucose, glycogen, fatty acid and amino acid metabolism, and redox reactions. Notably, there is a systematic decrease in capacity for mitochondrial ATP synthesis, mitochondrial area and cytochrome C expression. Nevertheless, the cellular ATP concentration was robustly elevated suggesting that the changes in transport capacity is not secondary to lack of cellular energy supply. The CPECs are smaller in the Ncbe ko model and the cellular $\mathrm{K}^{+}$contents lower, which is consistent with a reduced $\mathrm{Na}^{+}$entry and $\mathrm{Na}^{+}, \mathrm{K}^{+}$-ATPase activity in the cells. Thus, the loss of the putative main basolateral $\mathrm{Na}^{+}$-loader Ncbe seems to shift the epithelial cells from an efficient transporting program to an almost dormant program resembling aging and Alzheimer's disease.

\section{Supplementary information}

Supplementary information accompanies this paper at https://doi. org/10.1186/s12987-019-0162-5.

Additional file 1: Figure S1. Semi-quantitation of immunofluorescence images. (A) The original image stained for cytochrome C. (B) The same image including a manual region of interest (in green). (C) A binary mask of the fluorescence signal above threshold within the region of interest. (D) The resulting image of the minimum values for each pixel in the original image and the mask (i.e. the fluorescence signal above threshold within the region of interest). (E) The corresponding image of the nuclear fluorescence stain and outline of counted nuclei.

Additional file 2: Figure S2. Pairwise comparison of the 20 proteins semi-quantified by 2 of the 3 techniques applied in the study. (A) Plot depicting the protein abundance ratios (Ncbe wt/Ncbe ko) obtained by immunoblotting against mass spectrometry. (B) Similar plot of protein abundance ratios assessed by immunofluorescence against mass spectrometry. (C) Similar plot comparing the protein abundance ratios between immunofluorescence and immunoblotting techniques. Dotted lines are lines of perfect concordance; continuous lines represent bestfitted linear regression (Mean $\pm S E M, n=5$ ).

Additional file 3: Figure S3. Scatter plots showing the relative changes in abundance between Ncbe wt (black bars) and Ncbe ko (grey bars) CP among proteins involved in (A) glycolysis, (B) glycogen, (C) fatty acid and (D) amino acid metabolism as determined by quantitative mass spectrometry $(* p<0.05, X$ : Failed FDR of $1 \%, n=5)$. Mean values are normalized to control (Ncbe wt) and indicated by horizontal bars. Black triangles indicate data points from Ncbe wt CP, whereas gray circles represent data from Ncbe ko CP.

Additional file 4: Figure S4. Scatter plot showing the relative changes in abundance between Ncbe wt (black bars) and Ncbe ko (grey bars) CP among proteins involved in the tricarboxylic acid (TCA) cycle as determined by quantitative mass spectrometry $(* p<0.05$, X: Failed FDR of $1 \%, n=5)$. Mean values are normalized to control (Ncbe wt) and indicated by horizontal bars. Black triangles indicate data points from Ncbe wt CP, whereas gray circles represent data from Ncbe ko CP.

Additional file 5: Figure S5. Scatter plots showing the relative changes in abundance between Ncbe wt (black bars) and Ncbe ko (grey bars) CP among proteins involved in oxidative phosphorylation: (A) Complex I of the respiratory chain, (B) Complexes II, III, and IV of the respiratory chain as determined by quantitative mass spectrometry $\left(^{*} p<0.05, X\right.$ : Failed FDR of $1 \%, n=5)$. Mean values are normalized to control (Ncbe wt) and indicated by horizontal bars. Black triangles indicate data points from Ncbe wt CP, whereas gray circles represent data from Ncbe ko CP.

Additional file 6: Figure S6. Scatter plots showing the relative changes in abundance between Ncbe wt (black bars) and Ncbe ko (grey bars) ko CP among proteins involved in (A) mitochondrial ATP synthesis, (B) mitochondrial transport, and $(C)$ redox reactions as determined by quantitative mass spectrometry $\left({ }^{*} p<0.05, X\right.$ : Failed FDR of $\left.1 \%, n=5\right)$. Mean values are normalized to control (Ncbe wt) and indicated by horizontal bars. Black triangles indicate data points from Ncbe wt CP, whereas gray circles represent data from Ncbe ko CP.

Additional file 7: Table S1. Proteins identified by co-immunoprecipitation with anti-Ncbe antibody as bait.

\section{Abbreviations}

Ae2: anion exchanger 2; AMP: adenosine monophosphate; AMPK: AMPactivated protein kinase; AQP1: aquaporin 1; ATP: adenosine triphosphate; BH: Benjamini-Hochberg; BSA: bovine serum albumin; Ceacam-2: carcino-embryonic antigen-related cell adhesion molecule 2; CP: choroid plexus; CPECs: choroid plexus epithelial cells; CSF: cerebrospinal fluid; CTCF: CCCTC-binding factor; EDTA: ethylene diamine-tetraacetic acid; EGTA: ethylene glycol-bis( $\beta$ aminoethyl ether)-tetraacetic acid; FACS: fluorescence assisted cell sorting; FDR: false discovery rate; GO: gene ontology; GTF II-I: general transcription factor II-I; HBS: Hepes-buffered salt solution; IRBIT: IP3R binding protein released with inositol 1,4,5-trisphosphate; ko: knockout; MS: mass spectrometry; MS/ MS: tandem mass spectrometry; NBCe2: electrogenic $\mathrm{Na}^{+}: \mathrm{HCO}_{3}{ }^{-}$transporter 2; Ncbe: sodium-dependent chloride bicarbonate exchanger; NCE: normalized collision energy; $\mathrm{NKCC} 1: \mathrm{Na}^{+}, \mathrm{K}^{+}, 2 \mathrm{Cl}^{-}$cotransporter 1; $\mathrm{nLC}$ : nano liquid chromatography; OSR1: oxidative stress-responsive kinase 1; PANTHER: protein analysis through evolutionary relationships; PBS: phosphate buffered salt solution; PGC-1a: peroxisome proliferator-activated receptor $\gamma$ coactivator 1a; PLA: proximity ligation assay; PVDF: polyvinylidene difluoride; SIc4a10: solute carrier family 4 member 10; SPAK: SPS1-related Proline/Alanine-rich Kinase; TEG: trisEGTA; TMT: tandem mass tag; TUFM: mitochondrial Tu translation elongation factor; WNK: with-no lysine (K); wt: wildtype.

\section{Acknowledgements}

Ahmed Basim Abduljabar, Inger Merete S Paulsen, Helle Høyer, Vibeke Uhre, Christian V Westberg, Mie S Gandry, Peter Aakær Nielsen, and Kien Strand Olesen are thanked for expert technical assistance. We thank Hiroshi Shibuya at the Tokyo Medical and Dental University for the indicated pSPAK/OSR1 antibody. 


\section{Authors' contributions}

IBC, QW, ASB, MGS, HHD, CAH, RAF, JP. IBC, RAF, and JP conceived the work. IBC, $\mathrm{QW}, \mathrm{ASB}, \mathrm{MGS}, \mathrm{HHD}$, and JP were involved in data acquisition and/or analysis. IBC, QW, ASB, HHD, CAH, RAF, and JP interpreted data. IBC, ASB, and JP have drafted the work. All authors read and approved the final manuscript

\section{Funding}

Danish Council for Independent Research (Sundhed og Sygdom, Det Frie Forskningsråd, 0602-02404B), the Lundbeck Foundation (R54-A5378), the Novo Nordisk Foundation (NNF170C0028584), the Carlsberg Foundation, MEMBRANES, AU Ideas - Aarhus University Research Foundation (2012). Qi Wu is supported by a European Union Horizon 2020 Marie Skłodowska-Curie Individual Fellowship (Project No. 705682).

\section{Availability of data and materials}

The datasets generated during and/or analysed during the current study are available in the Interpret repository, http://interpretdb.au.dk/database/ CPE_TMT/CPE_TMT_proteome.html.

\section{Ethics approval and consent to participate}

All procedures conformed to Danish animal welfare regulations. The authors are licensed to breed the mouse strain by The Animal Experiments Inspectorate, Ministry of Food, Agriculture, and Fisheries of Denmark (j.n. 2012-15-2935-00004).

\section{Consent for publication}

Not applicable.

\section{Competing interests}

The authors declare that they have no competing interests.

Received: 9 October 2019 Accepted: 12 December 2019

Published online: 07 January 2020

\section{References}

1. de Rougemont J, Ames A 3rd, Nesbett FB, Hofmann HF. Fluid formed by choroid plexus; a technique for its collection and a comparison of its electrolyte composition with serum and cisternal fluids. J Neurophysiol. 1960;23:485-95.

2. Damkier HH, Brown PD, Praetorius J. Cerebrospinal fluid secretion by the choroid plexus. Physiol Rev. 2013;93(4):1847-92.

3. Welch K. Secretion of Cerebrospinal Fluid by Choroid Plexus of the Rabbit. Am J Physiol. 1963;205:617-24.

4. Davson $\mathrm{H}$, Segal MB. The effects of some inhibitors and accelerators of sodium transport on the turnover of $22 \mathrm{Na}$ in the cerebrospinal fluid and the brain. J Physiol. 1970;209(1):131-53.

5. Wright EM. Mechanisms of ion transport across the choroid plexus. J Physiol. 1972:226(2):545-71.

6. Oshio K, Watanabe H, Song Y, Verkman AS, Manley GT. Reduced cerebrospinal fluid production and intracranial pressure in mice lacking choroid plexus water channel Aquaporin-1. FASEB J. 2005:19(1):76-8.

7. Steffensen AB, Oernbo EK, Stoica A, Gerkau NJ, Barbuskaite D, Tritsaris K, et al. Cotransporter-mediated water transport underlying cerebrospinal fluid formation. Nat Commun. 2018;9(1):2167.

8. Gregoriades JMC, Madaris A, Alvarez FJ, Alvarez-Leefmans FJ. Genetic and pharmacologic inactivation of apical NKCC1 in choroid plexus epithelial cells reveals the physiological function of the cotransporter. Am J Physiol Cell Physiol. 2019;316:C525-44.

9. Damkier $\mathrm{HH}$, Aalkjaer $\mathrm{C}$, Praetorius J. $\mathrm{Na}$ +-dependent $\mathrm{HCO}_{3}{ }^{-}$import by the slc4a10 gene product involves $\mathrm{Cl}^{-}$export. J Biol Chem. 2010;285(35):26998-7007.

10. Giffard RG, Lee YS, Ouyang YB, Murphy SL, Monyer H. Two variants of the rat brain sodium-driven chloride bicarbonate exchanger (NCBE): developmental expression and addition of a PDZ motif. Eur J Neurosci. 2003;18(11):2935-45.

11. Wang CZ, Yano H, Nagashima K, Seino S. The Na+-driven $\mathrm{Cl}-/ \mathrm{HCO} 3-$ exchanger Cloning, tissue distribution, and functional characterization. J Biol Chem. 2000;275(45):35486-90.
12. Jacobs S, Ruusuvuori E, Sipila ST, Haapanen A, Damkier HH, Kurth I, et al Mice with targeted SIc4a10 gene disruption have small brain ventricles and show reduced neuronal excitability. Proc Natl Acad Sci USA. 2008;105(1):311-6.

13. Damkier HH, Praetorius J. Genetic ablation of Slc4a10 alters the expression pattern of transporters involved in solute movement in the mouse choroid plexus. Am J Physiol Cell Physiol. 2012;302(10):C1452-9.

14. Damkier HH, Prasad V, Hubner CA, Praetorius J. Nhe1 is a luminal Na+/ $\mathrm{H}+$ exchanger in mouse choroid plexus and is targeted to the basolateral membrane in Ncbe/Nbcn2-null mice. Am J Physiol Cell Physiol. 2009;296(6):C1291-300.

15. Christensen IB, Gyldenholm T, Damkier HH, Praetorius J. Polarization of membrane associated proteins in the choroid plexus epithelium from normal and slc4a10 knockout mice. Front Physiol. 2013;4:344.

16. Mi H, Huang X, Muruganujan A, Tang H, Mills C, Kang D, et al. PANTHER version 11: expanded annotation data from Gene Ontology and Reactome pathways, and data analysis tool enhancements. Nucleic Acids Res. 2017;45(D1):D183-9.

17. Mi H, Muruganujan A, Casagrande JT, Thomas PD. Large-scale gene function analysis with the PANTHER classification system. Nat Protoc. 2013;8(8):1551-66.

18. Damkier HH, Christensen $\mathrm{HL}$, Christensen IB, Wu Q, Fenton RA, Praetorius J. The murine choroid plexus epithelium expresses the $2 \mathrm{Cl}(-) / \mathrm{H}(+)$ exchanger $\mathrm{ClC}-7$ and $\mathrm{Na}(+) / \mathrm{H}(+)$ exchanger NHE6 in the luminal membrane domain. Am J Physiol Cell Physiol. 2018:314(4):C439-48.

19. Bost $F$, Kaminski L. The metabolic modulator PGC-1alpha in cancer. Am J Cancer Res. 2019;9(2):198-211.

20. Patel PR, Ramakrishnan SK, Kaw MK, Raphael CK, Ghosh S, Marino JS, et al. Increased metabolic rate and insulin sensitivity in male mice lacking the carcino-embryonic antigen-related cell adhesion molecule 2. Diabetologia. 2012;55(3):763-72.

21. Heinrich G, Ghosh S, Deangelis AM, Schroeder-Gloeckler JM, Patel PR, Castaneda TR, et al. Carcinoembryonic antigen-related cell adhesion molecule 2 controls energy balance and peripheral insulin action in mice. Gastroenterology. 2010;139(2):644-52, 52 e1.

22. He K, Guo X, Liu Y, Li J, Hu Y, Wang D, et al. TUFM downregulation induces epithelial-mesenchymal transition and invasion in lung cancer cells via a mechanism involving AMPK-GSK3beta signaling. Cell Mol Life Sci CMLS. 2016;73(10):2105-21

23. Pena-Hernandez R, Marques M, Hilmi K, Zhao T, Saad A, Alaoui-Jamali MA, et al. Genome-wide targeting of the epigenetic regulatory protein CTCF to gene promoters by the transcription factor TFll-I. Proc Natl Acad Sci USA. 2015;112(7):E677-86.

24. Park S, Hong JH, Ohana E, Muallem S. The WNK/SPAK and IRBIT/PP1 pathways in epithelial fluid and electrolyte transport. Physiol (Bethesda). 2012:27(5):291-9.

25. Hadchouel J, Ellison DH, Gamba G. Regulation of Renal Electrolyte Transport by WNK and SPAK-OSR1 Kinases. Annu Rev Physiol. 2016;78:367-89.

26. Bouzinova EV, Praetorius J, Virkki LV, Nielsen S, Boron WF, Aalkjaer C. $\mathrm{Na}+$-dependent $\mathrm{HCO}_{3}{ }^{-}$uptake into the rat choroid plexus epithelium is partially DIDS sensitive. Am J Physiol Cell Physiol. 2005;289(6):C1448-56.

27. Praetorius J, Nejsum LN, Nielsen S. A SCL4A10 gene product maps selectively to the basolateral plasma membrane of choroid plexus epithelial cells. Am J Physiol Cell Physiol. 2004;286(3):C601-10.

28. Masseguin C, LePanse S, Corman B, Verbavatz JM, Gabrion J. Aging affects choroidal proteins involved in CSF production in Sprague-Dawley rats. Neurobiol Aging. 2005;26(6):917-27.

29. Chen RL, Kassem NA, Redzic ZB, Chen CP, Segal MB, Preston JE. Agerelated changes in choroid plexus and blood-cerebrospinal fluid barrier function in the sheep. Exp Gerontol. 2009:44(4):289-96.

30. Praetorius J, Nielsen S. Distribution of sodium transporters and aquaporin-1 in the human choroid plexus. Am J Physiol Cell Physiol. 2006;291(1):C59-67.

31. Christensen HL, Paunescu TG, Matchkov V, Barbuskaite D, Brown D, Damkier HH, et al. The V-ATPase is expressed in the choroid plexus and mediates CAMP-induced intracellular $\mathrm{pH}$ alterations. Physiol Rep. 2017;5(1):e13072

32. Koltsova SV, Trushina Y, Haloui M, Akimova OA, Tremblay J, Hamet P, et al. Ubiquitous $[\mathrm{Na}+] \mathrm{i} /[\mathrm{K}+] \mathrm{i}$-sensitive transcriptome in mammalian cells: evidence for $\mathrm{Ca}(2+)$ i-independent excitation-transcription coupling. PLOS ONE. 2012;7(5):e38032. 
33. Li Z, Langhans SA. Transcriptional regulators of $\mathrm{Na}$, K-ATPase subunits. Front Cell Dev Biol. 2015;3:66.

34. Segal MB, Burgess AM. A combined physiological and morphological study of the secretory process in the rabbit choroid plexus. J Cell Sci. 1974;14(2):339-50.

35. Madhavi C, Jacob M. Light \& electron microscopic structure of choroid plexus in hydrocephalic guinea pig. Indian J Med Res. 1995;101:217-24.

36. Vinciguerra M, Arnaudeau S, Mordasini D, Rousselot M, Bens M, Vandewalle A, et al. Extracellular hypotonicity increases $\mathrm{Na}$, K-ATPase cell surface expression via enhanced $\mathrm{Na}+$ influx in cultured renal collecting duct cells. J Am Soc Nephrol. 2004;15(10):2537-47.

37. Kant S, Stopa EG, Johanson CE, Baird A, Silverberg GD. Choroid plexus genes for CSF production and brain homeostasis are altered in Alzheimer's disease. Fluids Barriers CNS. 2018;15(1):34.

38. Stopa EG, Tanis KQ, Miller MC, Nikonova EV, Podtelezhnikov AA, Finney EM, et al. Comparative transcriptomics of choroid plexus in Alzheimer's disease, frontotemporal dementia and Huntington's disease: implications for CSF homeostasis. Fluids Barriers CNS. 2018;15(1):18.

39. Gonzalez-Martinez LM, Avila J, Marti E, Lecuona E, Martin-Vasallo P. Expression of the beta-subunit isoforms of the Na, K-ATPase in rat embryo tissues, inner ear and choroid plexus. Biol Cell. 1994;81(3):215-22.
40. Kashgarian M, Biemesderfer D, Caplan M, Forbush B 3rd. Monoclonal antibody to $\mathrm{Na}$, K-ATPase: immunocytochemical localization along nephron segments. Kidney Int. 1985;28(6):899-913.

41. Kurihara K, Moore-Hoon ML, Saitoh M, Turner RJ. Characterization of a phosphorylation event resulting in upregulation of the salivary $\mathrm{Na}(+)$ K(+)-2Cl(-) cotransporter. Am J Physiol. 1999;277(6):C1184-93.

42. Alper SL, Stuart-Tilley A, Simmons CF, Brown D, Drenckhahn D. The fodrinankyrin cytoskeleton of choroid plexus preferentially colocalizes with apical $\mathrm{Na}+\mathrm{K}(+)$-ATPase rather than with basolateral anion exchanger AE2. J Clin Investig. 1994;93(4):1430-8.

43. Moriguchi T, Urushiyama S, Hisamoto N, lemura S, Uchida S, Natsume T, et al. WNK1 regulates phosphorylation of cation-chloride-coupled cotransporters via the STE20-related kinases, SPAK and OSR1. J Biol Chem. 2005:280(52):42685-93.

\section{Publisher's Note}

Springer Nature remains neutral with regard to jurisdictional claims in published maps and institutional affiliations.
Ready to submit your research? Choose BMC and benefit from:

- fast, convenient online submission

- thorough peer review by experienced researchers in your field

- rapid publication on acceptance

- support for research data, including large and complex data types

- gold Open Access which fosters wider collaboration and increased citations

- maximum visibility for your research: over $100 \mathrm{M}$ website views per year

At BMC, research is always in progress.

Learn more biomedcentral.com/submissions 